

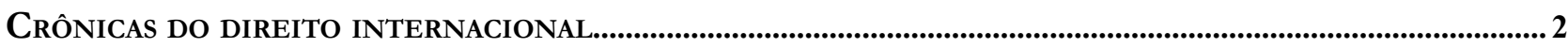

Nitish Monebhurrun

Alice Rocha da Silva

Julia Motte-Baumvol

Rafael Freitas de Oliveira

Roberta Greco

CRÔNICAS DO DIREITO INTERNACIONAL DOS INVESTIMENTOS .11

Nitish Monebhurrun

Reconhecimento E ExecuÇão de Sentenças Estrangeiras: anÁlise do projeto Em andamento na Conferência da Haia de Direito Internacional Privado

Nadia de Araujo

Fabrício Bertini Pasquot Polido

Os CASAMENTOS E AS PARCERIAS ENTRE PESSOAS DO MESMO SEXO NO DIREITO INTERNACIONAL PRIVAdO BRASILEIRO: ASPECTOS TRANSNACIONAIS DAS FAMÍLIAS CONTEMPORÂNEAS.

Bruno Rodrigues de Almeida

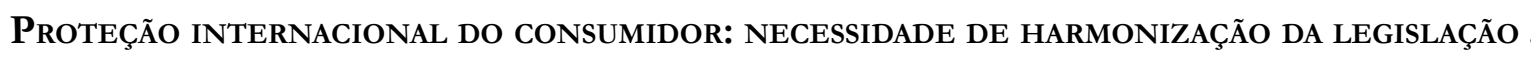
54

Héctor Valverde Santana

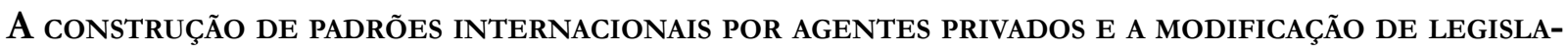
Ção NACIONAL: ALTERAÇÃo do PADRÃo DE CONTABILIDADE PARA EMPRESÁRIOS NO BRASIL.

Cleíse Nascimento Martins Costa

THE DEBATE ON COMPANIES' LIABILITY FOR INTERNATIONAL ENVIRONMENTAL DAMAGES: A COMPARISON BETWEEN THE JURISDiCTIONAL RULES OF THE EUROPEAN UNION AND THE UNITED STATES

Carina Costa de Oliveira

DesenVOlVIMENTO E APLICAÇÃo DA TEORIA dos VíNCUlOS MAIS ESTREITOS NO DIREITO INTERNACIONAL PRIVADO: POR UMA REDISCUSSÃO DO MÉTODO DE SOLUÇÃO DO CONFLITO DE LEIS 101

Jamile Bergamaschine Mata Diz

Rodrigo Vaslin Diniz

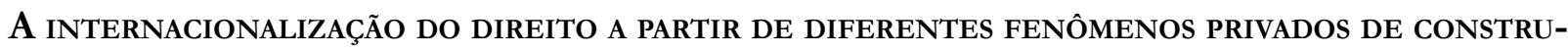
ÇÃO NORMATIVA 117

Fernando Lopes Ferraz Elias 
Leilane Serratine Grubba

Human TRAFFicking: IDENTIFYING FORCED LABOR IN MULTINATIONAL CORPORATIONS \& THE IMPLICATIONS OF LIABILITY

Tara M. Parente

Aplicação dos princípios UNIDROIT no Plano Brasil maior: o SUPRIMENTO de UMA lacuna NA POLÍTICA BRASILEIRA DE DESENVOLVIMENTO ECONÔMICO

Guilherme Freire de Melo Barros

Marcelle Franco Espíndola Barros

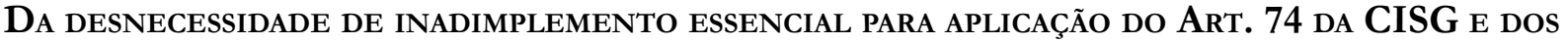
DANOS EFETIVAMENTE RECUPERÁVEIS

Renata Caroline Kroska

ESSAY ON UNEQUAL TREATIES AND MODERNITY THROUGH THE EXAMPLE OF BILATERAL INVESTMENT TREATIES

Nitish Monebhurrun

CONCEITOS DE RELAÇÕES INTERNACIONAIS E TEORIA DO DIREITO DIANTE DOS EFEITOS PLURALISTAS DA GLOBALIZAÇÃO: GOVERNANÇA GLOBAL, REGIMES JURÍDICOS, DIREITO REFLEXIVO, PLURALISMO JURÍDICO,

CORREGULAÇÃO E AUTORREGULAÇÃO . 216

Gabriela Garcia Batista Lima

\section{Outros Temas}

CONVENÇão SOBRE OS DIREITOS DAS PESSOAS COM DEFICIÊNCIA: COMO "INVISÍVEIS" CONQUISTARAM SEU ESPAÇO .230

Luana da Silva Vittorati

Matheus de Carvalho Hernandez 


\title{
DA DESNECESSIDADE DE INADIMPLEMENTO ESSENCIAL PARA APLICAÇÃO DO ART. 74 DA CISG E DOS DANOS EFETIVAMENTE RECUPERÁVEIS*
}

\section{About the unnecessity of fundamental breach for application of Article 74 CISG and about the damages effectively recoverable}

\author{
Renata Caroline Kroska**
}

\section{Resumo}

O presente trabalho iniciou-se pela conceituação de contrato, obrigação e adimplemento enfocando nas opções realizadas pela Convenção das Nações Unidas Sobre Contratos de Compra e Venda Internacional de Mercadorias (CISG). Em seguida, analisou-se o conceito de inadimplemento essencial partindo do artigo 25 da CISG, passando pelos principais pontos de dissenso doutrinário e procurando estabelecer um diálogo com julgamentos envolvendo a matéria. Definidos os contornos do inadimplemento essencial, o qual é imprescindível para a resolução do contrato, chegou-se ao ponto central do trabalho em que se verificou que não é necessária sua ocorrência para aplicação do artigo 74 da CISG, bastando que uma das partes tenha violado um dos deveres inerentes ao contrato ou à Convenção. Após a análise de situações concretas de inadimplemento nãoessencial em que seria possível a postulação de perdas e danos, partiu-se para a identificação dos danos considerados recuperáveis sob a égide do artigo 74 da CISG, classificando-os e definindo seus contornos para possível verificação em um caso concreto. Em seguida, foram lançadas algumas reflexões acerca do conceito de dano, o qual está em permanente aperfeiçoamento rumo à garantia da reparação integral e à inibição do enriquecimento sem causa. Por fim, teceramse algumas considerações acerca da consolidação no âmbito da CISG de que o dano ao renome ou à reputação comercial é de natureza material e não imaterial, contrariamente ao que os tribunais brasileiros têm decidido.

Palavras-chave: CISG. Inadimplemento essencial. Perdas e danos.

\section{Abstract}

This work was initiated by the conceptualization of contract, obligation and due performance by focusing on the choices made by the United Nations Convention on Contracts for the International Sale of Goods (CISG). Then, we analyzed the concept of essential breach of Article 25 from the starting of CISG, through the main points of doctrinal dissent and seeking to establish a dialogue with judgments involving matters. Defined the contours of the default key, which is

* Recebido em 01.04.2014 Aceito em 26.05.2014

**Advogada. Estudante de Especialização na Escola da Magistratura Federal do Paraná - ESMAFE PR.

E-mail: renatakroska.adv@gmail.com essential for the solving of the contract, we have reached to the point of the work focused on what was found that it is enough that one of the parts has violated one of the duties of the contract or the Convention. After the analysis of non essential concrete situations of default we were running through postulation of damages and broke for the identification of damage considered recoverable under 
the aegis of Article 74 of the CISG, classifying and defining them and their outlines for possible check in a particular case. Then, we launched some reflections about the concept of damage, which are in continuous improvement towards ensuring full compensation and inhibition of unjust enrichment. Finally, we wove some considerations about consolidation within the CISG that the damage to the reputation or business reputation of material nature and is not immaterial, unlike that Brazilian courts have decided.

Keywords: CISG. Essential default. Damages.

\section{Introdução}

A ratificação brasileira em 2013 da Convenção das Nações Unidas sobre Contratos para a Compra e Venda Internacional de Mercadorias (CISG) fez com que, a partir de abril de 2014, a Convenção passasse a ser amplamente aplicável às relações de compra e venda internacional em que uma das partes, vendedor ou comprador, tenha estabelecimento no Brasil.

A internalização da CISG desafia os operadores do direito na medida em que lhes impõe o conhecimento de um diploma jurídico de complexidade ímpar que busca a consolidação dos costumes internacionais aliada à harmonização dos sistemas legais de common e de civil law.

Considerando que os primeiros países a ratificar a CISG se depararam com conflitos envolvendo sua interpretação já no fim da década de 1980, é evidente que as decisões emanadas dos seus tribunais jurisdicionais e arbitrais contribuíram para conformação de alguns conceitos abertos trazidos pela CISG, de modo que conhecer a Convenção é também conhecer as decisões que a aplicaram.

Assim, partindo-se da premissa que comprometerse com a CISG é comprometer-se também com a sua interpretação uniforme para proporcionar segurança jurídica, o trabalho analisa não apenas a doutrina, mas também decisões que envolveram a aplicação da Convenção.

O trabalho se concentra em um dos aspectos mais problemáticos da compra e venda que consiste naqueles casos em que a relação jurídica não se desenvolve como deveria. Para tais situações, o art. 74 da CISG prevê a possibilidade de requerimento de perdas e danos pela parte prejudicada.
Entretanto, a polêmica se apresenta quanto aos tipos de violações que autorizariam a atribuição dessas perdas e danos. Seria necessária uma violação essencial nos termos do art. 25 da CISG ou outras violações poderiam ensejar a condenação em perdas e danos?

Nesse ponto, tem-se por necessária a problematização do conceito de inadimplemento essencial para o adequado desenvolvimento do tema, ademais porque sua identificação tem especial relevância prática, uma vez que somente diante de sua ocorrência é que se autoriza a resolução unilateral do contrato.

A partir da análise do conceito de inadimplemento essencial, parte-se para verificação acerca da necessidade de sua existência para atribuição de perdas e danos, seguindo para um exame casuístico, cujas situações encontradas foram classificadas em três grupos: entrega de mercadorias em local diferente do pactuado; atraso na entrega de mercadorias; não conformidade das mercadorias entregues.

Em seguida, analisam-se as categorias de danos passíveis de indenização de acordo com o art. $74 \mathrm{da}$ CISG, conforme a doutrina que os classifica em: perda direta ou perda por incumprimento, danos incidentais, danos consequentes e lucros cessantes.

Por fim, traz-se uma reflexão sobre o conceito de dano que já não se apresenta adequado às relações comerciais contemporâneas e que sugere uma superação do paradigma puramente econômico.

\section{Contrato, obrigação, adimplemento e a convenção das nações unidas sobre contratos de compra e venda internacional de mercadorias (CISG)}

A Convenção da ONU, proposta nesta análise, consiste na lei uniforme mais bem-sucedida ${ }^{1}$ sobre Contratos de Compra e Venda Internacional de Mercadorias, a qual aborda tanto a formação desses contratos quanto as obrigações das partes. Diante da menção repetida ao termo contrato, torna-se conveniente recordar que ele consiste no principal instrumento de circulação de riquezas ou nas palavras de Enzo Roppo ${ }^{2}$, trata-se da "veste jurídico-formal de operações econômicas".

1 HONNOLD, John. O. Uniform law for international sales under the 1980 United Nations Convention. Disponível em: <http:/ / www.cisg. law.pace.edu/cisg/biblio/honnold.html>. Acesso em: 02. set. 2013. 2 ROPPO, Enzo. O contrato. Coimbra: Almedina, 2009. p. 11. 
Esse conceito econômico de contrato mostra-se muito mais eficaz a uma pretensão unificadora do que os conceitos jurídicos atribuíveis ao contrato, pois, cada ordenamento atribui contornos próprios ao instituto ${ }^{3}$ criando um verdadeiro efeito polissêmico que dificulta sobremaneira a uniformização regulamentadora à que se propõe a CISG.

Partindo do conceito econômico acima exposto, tem-se que o contrato revestirá uma operação econômica encerrando as partes numa relação jurídica obrigacional caracterizada pelas posições de crédito e débito ${ }^{4}$. $\mathrm{Na}$ Convenção de Viena, verifica-se uma opção por denominar as posições jurídicas por vendedor e comprador.

O vendedor, de acordo com o artigo 30 da CISG, teria como prestações primordiais entregar as mercadorias, transmitir a propriedade sobre elas e, sendo o caso, a remeter os respectivos documentos. Em contrapartida, o artigo 53 da CISG impõe ao comprador as prestações de pagar o preço das mercadorias e recebê-las nas condições estabelecidas no contrato e na Convenção.

Cumpre recordar que a relação jurídica obrigacional está polarizada pelo adimplemento ${ }^{5}$, o que, nas palavras de Judith Costa ${ }^{6}$, significa dizer que o adimplemento é a "finalidade da relação, que tem por sua própria natureza caráter transitório, nascendo para extinguir-se".

Ainda segundo o magistério de Judith $\operatorname{Costa}^{7} \mathrm{o}$ adimplemento possui um sentido lato e um sentido estrito. $O$ sentido lato corresponde à satisfação do credor, independentemente se voluntária ou forçada. O

3 Sobre a origem desse fenômeno polissêmico do contrato Enzo Roppo afirma que: "o direito dos contratos não se limita a revestir passivamente a operação económica de um véu legal de per si não significativo, a representar a sua mera tradução jurídico formal, mas amiúde, tende a incidir sobre as operações económicas (ou até sobre a sua dinâmica complexiva), de modo a determinalas e orientá-las segundo objetivos que bem se podem apelidar de políticos lato sensu". ROPPO, Enzo. O contrato. Coimbra: Almedina, 2009. p. 23.

4 SILVA, Clóvis V. Couto e. A obrigação como processo. Rio de Janeiro: FGV, 2007. p. 19.

5 SILVA, Clóvis V. Couto e. A obrigação como processo. Rio de Janeiro: FGV, 2007. p. 23.

6 COSTA, Judith Martins. Comentários ao novo código civil: do direito das obrigações: do adimplemento e da extinção das obrigações: arts. 304 a 388. 2. ed. Rio de Janeiro: Forense, 2006. v. 5. t. 1. p. 30 .

7 COSTA, Judith Martins. Comentários ao novo código civil: do direito das obrigações: do adimplemento e da extinção das obrigações: arts. 304 a 388. 2. ed. Rio de Janeiro: Forense, 2006. v. 5. t. 1. p. 123 . sentido estrito "designa o cumprimento da prestação devida, de modo voluntário e exato, no tempo lugar e forma convencionada, com satisfação do credor, desatando o vínculo." 8

Voltando os olhos para CISG, observa-se que é adotado o conceito estrito de adimplemento quando no artigo 25 define-se como inadimplemento essencial aquela violação que priva uma parte do que ela legitimamente esperava da outra.

De outro vértice, a CISG preocupa-se em proporcionar a satisfação forçada do credor quando verificado um inadimplemento essencial por meio de mecanismos previstos no intervalo dos artigos 74 a 76 , entre os quais se destaca a disciplina das perdas e danos.

O próximo tópico destina-se a analisar o conceito de inadimplemento essencial, anteriormente esboçado, previsto no artigo 25 da CISG, tratando-se com especificidade dos seus requisitos e abordando as suas consequências para as partes.

\section{0 conceito de inadimplemento essencial do contrato na CISG}

O artigo 25 da Convenção de Viena sobre Contratos de Compra e Venda Internacional de Mercadorias (CISG) se encarrega de definir o inadimplemento essencial e o faz de forma autônoma, sem apoderar-se de conceitos existentes nas leis domésticas?.

Essa observação é especialmente relevante para afastar da interpretação do art. 25 da CISG a doutrina inglesa de violação fundamental do contrato que, como bem adverte Michael WILL, consiste em uma falsa predecessora $^{10}$.

Identificar o inadimplemento essencial é de vital importância, pois somente diante de sua ocorrência a parte lesada poderia impor a resolução do contrato, tratando-se de verdadeiro pré-requisito ${ }^{11}$.

8 COSTA, Judith Martins. Comentários ao novo código civil: do direito das obrigações: do adimplemento e da extinção das obrigações: arts. 304 a 388. 2. ed. Rio de Janeiro: Forense, 2006. v. 5. t. 1. p. 123.

9 FERRARI, Franco. Fundamental breach of contract under the UN sales convention: 25 years of article 25 CISG. Disponível em: $\quad<$ http://cisgw3.law.pace.edu/cisg/biblio/ferrari14.html $>$. Acesso em: 05 ago. 2013.

10 WILL, Michael. Article 25: commentary. Disponível em: $<$ http://cisgw3.law.pace.edu/cisg/biblio/will-bb25.html $>$. Acesso em: 05 ago. 2013.

11 WILL, Michael. Article 25: commentary. Disponível em: $<$ http://cisgw3.law.pace.edu/cisg/biblio/will-bb25.html $>$. Acesso em: 05 ago. 2013. 
O inadimplemento essencial figura, portanto, como verdadeira condição sine qua non para a resolução do contrato. Assim, em caso de violação não essencial do contrato a parte frustrada, em regra, não poderá dispor deste remédio, prevalecendo o princípio da conservação do contrato, impedindo-lhe a extinção por resolução ${ }^{12}$.

Para se definir o inadimplemento essencial há que se partir necessariamente do próprio artigo 25 da CISG que o descreve da seguinte forma:

A violação ao contrato por uma das partes é considerada como essencial se causar à outra parte prejuízo de tal monta que substancialmente a prive do resultado que poderia esperar do contrato, salvo se a parte infratora não tiver previsto e uma pessoa razoável da mesma condição e nas mesmas circunstâncias não pudesse prever tal resultado ${ }^{13}$.

Como se pode observar o artigo faz uso das fórmulas gerais privação substancial e legítima expectativa contratual, apresentando como contraponto à responsabilização da parte infratora a regra da previsibilidade do dano. Nos tópicos a seguir procederse-á a análise de cada um desses elementos que compõem o conceito de inadimplemento substancial.

\subsection{Privação substancial e legítima expectativa contratual}

O conceito de privação substancial, segundo Alexander Lorenz ${ }^{14}$, estaria atrelado às obrigações do

12 Frederico GLITZ aponta que a doutrina compreende a conservação do contrato sob diferentes perspectivas: como regra de interpretação do negócio jurídico, cujo objetivo é procurar atribuir efeito ao contrato; como alternativa à decretação de nulidade do contrato, utilizando-se os instrumentos da confirmação, redução, conversão entre outros; como diretriz de revisão contratual na qual se prima por reequilibrar o contrato a fim de garantir justiça contratual entre as partes; como dever de renegociação do contrato instituído em cláusula contratual; e por fim, como óbice à extinção do contrato visando evitar a resolução injustificada do contrato. GLITZ, Frederico Eduardo Zenedin. Favor Contractus: alguns apontamentos sobre o princípio da conservação do contrato no direito positivo brasileiro e no direito comparado. Disponível em: <http://www. fredericoglitz.adv.br/biblioteca_detalhe/51/favor-contractusalguns-apontamentos-sobre-o-principio-da-conservacao-docontrato-no-direito-positivo-brasileiro-e-no-direito-comparado $>$. Acesso em: 05 ago.2013.

13 CONVENÇÃO das nações unidas sobre contratos de compra e venda internacional de mercadorias (CISG). Dados da publicação. Trad. Eduardo Grebler; Gisely Radael. Disponível em: $<$ http://www.cisg-brasil.net/doc/egrebler2.htm>. Acesso em 16 abr. 2013.

14 LORENZ, Alexander. Fundamental breach under CISG. vendedor e do comprador respectivamente previstas nos artigos 30 e 53 da CISG.

Sob essa perspectiva, o vendedor incorreria em inadimplemento essencial quando não entregasse as mercadorias, deixasse de lhes transferir a propriedade ou não remetesse os documentos pertinentes. De outro vértice, o comprador cometeria inadimplemento essencial quando não pagasse o preço das mercadorias, ou não as aceitasse nas condições previstas no contrato ou na CISG.

De acordo com Lorenz ${ }^{15}$ a CISG forneceria os contornos daquelas obrigações consideradas essenciais. Todavia, há doutrinadores como Franco Ferrari ${ }^{16}$ que entendem que a CISG não faz distinção entre violação das obrigações principais e violação das obrigações acessórias.

De acordo com essa concepção, o descumprimento de uma obrigação que não é principal, mas acessória, pode ser considerada um inadimplemento essencial, desde que esteja intimamente ligada à troca de bens ou que as partes a tenham subordinado às regras da CISG.

Em contrapartida, Leonardo Graffi ${ }^{17}$ sustenta que a definição de privação substancial -- estaria atrelada à expectativa contratual da parte lesada, sendo este um elemento fundamental para determinar se uma quebra de contrato é substancial ou não.

Nessa esteira, a privação deve ser considerada substancial quando a parte lesada perde o interesse na satisfação da obrigação, prescindindo de análise se esta obrigação é de caráter principal ou acessório.

Entretanto, a perda de interesse na satisfação do contrato deve se fundamentar numa expectativa legítima, ou seja, "o foco é a privação substancial da expectativa contratual da parte prejudicada" 18 .

Disponível em: <http://cisgw3.law.pace.edu/cisg/biblio/lorenz. html> Acesso em: 05 ago.2013.

15 LORENZ, Alexander. Fundamental breach under CISG. Disponível em: <http://cisgw3.law.pace.edu/cisg/biblio/lorenz. html> Acesso em: 05 ago.2013.

16 FERRARI, Franco. fundamental breach of contract under the UN sales convention: 25 years of article 25 CISG. Disponível em: <http:/ / cisgw3.law.pace.edu/cisg/biblio/ferrari14.html>. Acesso em: 05 ago.2013.

17 GRAFFI, Leonardo. Case Law on the Concept of "Fundamental Breach" in the Vienna Sales Convention. Disponível em: < http://www. cisg.law.pace.edu/cisg/biblio/graffi.html>. Acesso em: 05 ago. 2013.

18 BIJL, Maartje. Fundamental breach in documentary sales contracts the doctrine of strict compliance with the underlying sales contract. Disponível em: $<$ http://cisgw3.law.pace.edu/cisg/biblio/bijl.html>. Acesso em: 
Sobre as expectativas das partes contratantes, Chengwei LIU $^{19}$ defende serem aquelas que podem ser extraídas do instrumento contratual, tais como as disposições acerca da alocação do risco, ressalvando, todavia, os usos habituais e as disposições da Convenção como fontes de expectativas legítimas entre as partes.

De outro vértice, Franco Ferrari propõe claramente que as origens da legítima expectativa excedem o instrumento contratual, abrangendo também as negociações que precederam o contrato ${ }^{20}$.

Um exemplo prático em que se acolheu a tese segundo a qual o inadimplemento é essencial quando a violação contratual priva a parte lesada da legítima expectativa fazendo-a perder o interesse no cumprimento do contrato foi o caso dos sapatos julgado pelo Tribunal de Apelação de Frankfurt ${ }^{21}$.

Trata-se do caso em que um fabricante italiano produziu 130 pares de sapatos conforme especificações fornecidas pelo comprador alemão em caráter de exclusividade, porém, durante uma feira de exposições, exibiu alguns pares desses sapatos produzidos de acordo com tais especificações, inclusive contendo a marca de titularidade do comprador.

O Tribunal decidiu que a violação do dever acessório de exclusividade caracterizou quebra fundamental porque colocou o objeto do contrato seriamente em perigo de modo que a parte lesada legitimamente perdeu o interesse no seu cumprimento.

Caso semelhante foi levado à apreciação da Corte de Apelação de Grenoble ${ }^{22}$ na França: um vendedor francês e um comprador estadunidense concluíram em 1991 um contrato para venda de roupas as quais seriam entregues parceladamente.

05. ago. 2013. Tradução de livre de: The focus is on the substantial deprivation of the contractual expectation of the aggrieved party.

19 LIU, Chengwei. The concept of fundamental breach: perspectives from the CISG, UNIDROIT principles and PECL and case law. Disponível em: <http://www.cisg.law.pace.edu/cisg/biblio/liu8. html>. Acesso em: 05. ago. 2013.

20 FERRARI, Franco. Fundamental breach of contract under the UN sales convention: 25 years of article 25 CISG. Disponível em: $<\mathrm{http}: / /$ cisgw3.law.pace.edu/cisg/biblio/ferrari14.html>. Acesso em: 05 ago. 2013.

21 ALEMANHA. Tribunal de Apelação de Frankfurt. Julgamento em: 17, de setembro de 1991. Disponível em: <http:// cisgw3.law.pace.edu/cases/910917g1.html>. Acesso em: 05 ago. 2013.

22 FRANÇA. Corte de Apelação de Grenoble. Julgado em: 22, de fevereiro de 1995. Disponível em: < http://www.unilex.info/case.cf $\mathrm{m}$ ? pid $=1 \& \mathrm{do}=$ case\&id $=83 \&$ step $=$ Abstract $>$. Acesso em: 14 ago. 2013.
O comprador, a pedido do vendedor, declarou a intenção de revender as mercadorias a um distribuidor na América do Sul, de maneira que, após a entrega da primeira parcela dos bens, o vendedor solicitou ao comprador a apresentação do comprovante de entrega dos produtos ao revendedor dessa localidade. O comprador recusou-se a exibir o comprovante e o vendedor informado de que as mercadorias foram vendidas a um revendedor na Espanha, recusou-se a entregar as outras parcelas.

O comprador reclamava perdas e danos por quebra do contrato, enquanto o vendedor alegava danos sob o argumento de que a venda de seus produtos na Europa havia sido prejudicada pela distribuição paralela feita pelo cliente do comprador.

O tribunal considerou que a declaração de que as mercadorias seriam entregues a um distribuidor na América do Sul era de fundamental importância para o vendedor e que a violação da cláusula contratual de destinação final da mercadoria por parte do comprador, além de contrariar a boa-fé, consistiu em uma violação essencial do contrato, sendo legítima a pretensão do vendedor de resolução do contrato.

Em ambos os casos, a violação de uma obrigação acessória fundamentou a resolução do contrato sob o argumento de que o seu cumprimento era de especial interesse da parte contratante. Entretanto, há que se recordar que a segunda parte do artigo 25 da CISG faz menção à regra da previsibilidade, cuja análise é realizada a seguir.

\subsection{Previsibilidade}

A segunda parte do artigo 25 da CISG contém hipótese de exceção à resolução por inadimplemento essencial. Trata-se das situações em que o risco não foi previsto pela parte faltosa e nem o teria sido por uma pessoa razoável, com idêntica qualificação e colocada na mesma situação.

Isso implica dizer que a parte faltosa que invoca e prova a imprevisibilidade do risco pode evitar a resolução do contrato, mesmo nas situações em que a parte lesada sofreu um prejuízo. ${ }^{23}$

23 GRAFFI, Leonardo. Case law on the concept of "Fundamental Breach" in the Vienna sales convention. Disponível em: < http://www. cisg.law.pace.edu/cisg/biblio/graffi.html >. Acesso em: 05 ago. 2013. 
As situações em que a imprevisibilidade do prejuízo pode ser invocada são fixadas pelas partes e devem constar do contrato primando-se por definir quais obrigações são da essência do contrato, pois assim "haverá pouco espaço para provar que a violação causou um prejuízo imprevisível." 24

Considerando que a CISG não define o momento decisivo para determinação da previsibilidade ${ }^{25}$, discute-se doutrinariamente quando o prejuízo deve ter sido previsto, se no momento da conclusão do contrato, ou se outras comunicações trocadas entre as partes podem ser consideradas para atribuição da previsibilidade. A polêmica é muito bem sintetizada por Graffi nos seguintes termos:

Enquanto alguns autores argumentam que a importância de uma obrigação deve ser determinada apenas em função das circunstâncias conhecidas na conclusão do contrato, outros autores consideram igualmente importante qualquer informação posterior que pode indicar interesse das partes em receber o desempenho ${ }^{26}$.

Leonardo Graffi ${ }^{27}$, que compõe o segundo grupo, argumenta que essa concepção é a que mais se coaduna com a boa-fé e cita decisões em que informações trocadas entre as partes, para além do momento da conclusão do contrato, foram consideradas vinculativas. $\mathrm{O}$ autor cita decisão do Supremo Tribunal Alemão ${ }^{28} \mathrm{em}$

24 GRAFFI, Leonardo. Case law on the concept of "Fundamental Breach" in the Vienna sales convention. Disponível em: < http://www. cisg.law.pace.edu/cisg/biblio/graffi.html>. Acesso em: 05 ago. 2013. Tradução livre de: "When the contract expressly states that performance of an obligation is of essence, there will be little room for proving that the breach caused an unforeseeable detriment".

25 FERRARI, Franco. Fundamental breach of contract under the UN sales convention: 25 years of article 25 CISG. Disponível em: <http:/ / cisgw3.law.pace.edu/cisg/biblio/ferrari14.html>. Acesso em: 05 ago. 2013.

26 GRAFFI, Leonardo. Case Law on the concept of "Fundamental Breach" in the Vienna sales convention. Disponível em: < http://www. cisg.law.pace.edu/cisg/biblio/graffi.html>. Acesso em: 05 ago. 2013. Tradução livre de: While some authors argue that the importance of an obligation must be determined only in light of the circumstances known at the conclusion of the contract, other authors deem equally important any subsequent information that may indicate the parties' interest in receiving performance.

27 GRAFFI, Leonardo. Case law on the concept of "Fundamental Breach" in the Vienna sales convention. Disponível em: < http://www. cisg.law.pace.edu/cisg/biblio/graffi.html>. Acesso em 05 ago. 2013.

28 ALEMANHA. Supremo Tribunal Federal Alemão. Julgamento em: 31, de outubro de 2001. Disponível em: <http:// cisgw3.law.pace.edu/cases/011031g1.html>. Acesso em: 08 ago.2013. que se decidiu que termos e condições gerais previstos em instrumento apartado, mas disponibilizados à outra parte compunham e contrato celebrado entre as partes.

Em sentido diametralmente oposto Franco Ferrari ${ }^{29}$, e segundo ele a maioria da doutrina, defende que o momento da previsão do prejuízo é o da conclusão do contrato, pois, do contrário, isto é, conferindo-se importância às comunicações realizadas após esse momento estar-se-ia permitindo a alteração unilateral do contrato.

Há ainda o standard de comportamento segundo o qual o dano não teria sido igualmente previsto por uma pessoa razoável, com idêntica qualificação e colocada na mesma situação da parte faltosa. Considerando que é pouco provável que a parte faltosa admita ter previsto o prejuízo em questão $0^{30}$, pois isso o conduziria à sucumbência antecipada, o padrão da pessoa razoável é essencial para que o julgador possa analisar a situação com objetividade ${ }^{31}$.

De todo o exposto, percebe-se que diante de uma violação contratual deve-se primeiramente analisar se esse inadimplemento é essencial ou não, pois somente aquele pode ensejar a resolução do contrato.

Para configurar inadimplemento essencial é necessário o preenchimento de alguns requisitos: 1) uma das partes tem que ter causado à outra parte um prejuízo; 2) esse prejuízo tem que ter privado a outra parte de uma prestação essencial e legitimamente esperada do negócio; 3) esse prejuízo não deve ter sido previsto pela parte faltosa e não poderia ter sido previsto por uma pessoa razoável com a mesma qualificação em situação semelhante.

Recorde-se que a Convenção nos artigos $30 \mathrm{e}$ 53 fornece uma pista das obrigações geralmente consideradas essenciais para o comprador e o vendedor, todavia, as partes podem dispor livremente acerca das prestações que consideram essenciais ao negócio.

29 FERRARI, Franco. Fundamental breach of contract under the UN sales convention: 25 years of article 25 CISG. Disponível em: <http:/ / cisgw3.law.pace.edu/cisg/biblio/ferrari14.html>. Acesso em: 05.ago.2013.

30 BIJL, Maartje. Fundamental breach in documentary sales contracts the doctrine of strict compliance with the underlying sales contract. Disponível em: $<$ http://cisgw3.law.pace.edu/cisg/biblio/bijl.html>. Acesso em: 05 ago. 2013.

31 FERRARI, Franco. Fundamental breach of contract under the UN sales convention: 25 Years of Article 25 CISG. Disponível em: $<$ http://cisgw3.law.pace.edu/cisg/biblio/ferrari14.html>. Acesso em: 05 ago. 2013. 
Contudo, os posicionamentos doutrinários de Graffir $^{32}$ e Ferrari ${ }^{33}$ expostos no tópico sobre a privação substancial e legítima expectativa, elucidam a existência de dissenso doutrinário quanto à fonte dessa legítima expectativa: se somente o contrato deve ser considerado ou se devem ser tomadas outras declarações das partes feitas para além do instrumento contratual.

Não menos polêmica é a regra da previsibilidade, em que Ferrari ${ }^{34}$ e Graffi ${ }^{35}$ divergem se o momento decisivo para previsão dos danos é o da celebração do contrato ou se podem ser consideradas outras trocas de informações entre as partes.

\section{Da desnecessidade do inadimplemento essencial do contrato para aplicação do art. 74}

Anteriormente, foi destacado que somente o inadimplemento essencial enseja a resolução do contrato e que tal inadimplemento pode corresponder tanto à violação de uma obrigação principal quanto acessória, uma vez que a CISG não atribui consequências específicas para cada uma dessas violações.

A questão que se pretende resolver agora parte do pressuposto de que houve uma violação contratual que não ensejou resolução por não ter sido considerada um inadimplemento essencial. Nesse caso cumpre indagar se a parte lesada teria direito à reparação de eventuais danos decorrentes de um inadimplemento não -essencial?

Atualmente prevalece o entendimento de que a violação de qualquer das obrigações estipuladas pelo contrato ou pela Convenção geram o direito de reclamar perdas e danos, não havendo que se tratar de uma violação fundamental ${ }^{36}$. Esse entendimento

32 GRAFFI, Leonardo. Case law on the concept of "Fundamental Breach" in the Vienna sales convention. Disponível em: < http://www. cisg.law.pace.edu/cisg/biblio/graffi.html>. Acesso em: 05 ago. 2013.

33 FERRARI, Franco. Fundamental breach of contract under the UN sales convention: 25 years of article 25 CISG. Disponível em: <http:/ / cisgw3.law.pace.edu/cisg/biblio/ferrari14.html>. Acesso em: 05.ago. 2013.

34 FERRARI, Franco. Fundamental breach of contract under the UN sales convention: 25 years of article 25 CISG. Disponível em: <http:/ / cisgw3.law.pace.edu/cisg/biblio/ferrari14.html>. Acesso em: 05 ago. 2013.

35 GRAFFI, Leonardo. Case law on the concept of "Fundamental Breach" in the Vienna sales convention. Disponível em: < http://www. cisg.law.pace.edu/cisg/biblio/graffi.html>. Acesso em: 05 ago. 2013.

36 SCHWENZER, Ingeborg. Section 11, Damages. In: decorre dos artigos 45(1) e 61(1) da CISG os quais preveem expressamente o direito de o comprador e o vendedor, respectivamente, reclamarem perdas e danos em face da outra parte que não executou "qualquer das obrigações que resultam do contrato de compra e venda ou da presente Convenção".

De acordo com Jürgen Basedow ${ }^{37}$, a fórmula eleita pela CISG de estabelecer um conceito uniforme de violação contratual que abrange toda e qualquer forma de descumprimento fixando-lhes os mesmos remédios é simples aos olhos dos operadores do direito comum, porém, significa uma quebra de tradição em muitos países de civil law. Esse autor afirma que a adesão à Convenção modificou a forma como o Código Civil Alemão regula o inadimplemento, o qual passou a prever em 2002 a responsabilização pelo incumprimento de qualquer uma das obrigações assumidas pela parte contratante, na linha do que estabelece a Convenção.

Venceslau Tavares Costa filho ${ }^{38}$ ressalta que o Código Civil Alemão (BGB), antes da reforma, previa como remédios contratuais apenas a rescisão do contrato e a redução do preço para casos em que se verificasse defeito, de modo que a substituição do produto ou o conserto não consistiam em alternativas abrangidas pela lei.

Paralelamente ao BGB, os artigos 441 e 442 do Código Civil Brasileiro oferecem apenas as soluções da devolução da coisa e da redução do preço, de maneira que em nosso ordenamento somente o Código de Defesa do Consumidor prevê expressamente a possibilidade de substituir o produto ou exigir-lhe o conserto.

Entretanto, para além do que preconiza a lei civil brasileira, é conveniente recordar que o Código de Processo Civil Brasileiro prevê a tutela específica das obrigações de fazer, não fazer e de dar nos artigos 461 e 461-A do CPC permitindo ao credor optar entre perdas e danos e satisfação específica da obrigação.

SCHLECHTRIEM, Peter; SCHWENZER, Ingeborg. Commentary on the UN Convention on the International Sale of Goods (CISG). 3. ed. Oxford: Oxford University Press, 2010. p. 1003. Nesse mesmo sentido: SAIDOV, Djakhongir. The law of damages in the international sale of goods. The CISG and other International Instruments. Portland: Hart Publishing, 2008. p. 21.

37 BASEDOW. Jürgen. Towards a Universal doctrine of breach of contract: the impact of the CISG. Disponível em: <http://www.cisg. law.pace.edu/cisg/biblio/basedow.html> Acesso em: 13. ago. 2013.

38 COSTA FILHO, Venceslau Tavares. Alguns aspectos da lei para a modernização do direito das obrigações na Alemanha. Revista de Direito Privado, São Paulo: RT, ano 12, n. 45, p. 147-164, jan./mar. 2011. 
Frise-se que a satisfação específica da obrigação é ponto de grande dissidência entre os sistemas de Common e de Civil Law. Embora aqueles permitam que a parte pleiteie o desempenho específico, a base decisória é sempre discricionária e leva em conta as regras de equidade, de modo que os pedidos são em sua maioria rejeitados por se considerar que a indenização pelo equivalente protege os interesses do credor de forma satisfatória.

De outro vértice, nos países de jurisdição de Civil Law, o desempenho específico é uma consequência natural da promessa do devedor, ainda que o pleito por perdas e danos seja mais usual por ser considerado mais eficiente e menos complicado, é cediço que nesses países um pedido dessa natureza dificilmente é julgado improcedente ${ }^{39}$.

Assim, se por um lado a CISG não previu expressamente a satisfação específica da obrigação, por outro, ela assegurou à parte lesada o direito de pleitear perdas e danos em face da violação de quaisquer das obrigações decorrentes do contrato ou da Convenção. A compreensão das situações em que uma violação não enseja resolução contratual, mas permite o pedido de perdas e danos será o próximo assunto a ser abordado pelo trabalho.

\section{Situações de inadimplemento não essencial em que podem ser reclamadas perdas e danos}

Anteriormenteesclareceu-sequeosinadimplementos não essenciais podem ensejar pedido de reparação de danos, ainda que não deem causa à resolução do contrato. As situações em que isso seria possível, de acordo com as decisões já proferidas pelos tribunais, foram dividas em três grupos: entrega de mercadorias em local diferente do inicialmente pactuado; atraso na entrega das mercadorias e não conformidade das mercadorias entregues.

\subsection{Entrega de mercadorias em local diferente do inicialmente pactuado}

A primeira situação digna de destaque referese à entrega da mercadoria em local diferente do inicialmente pactuado, violação que, a princípio, não configura inadimplemento essencial e, portanto,

39 BASEDOW. Jürgen. Towards a universal doctrine of breach of contract: the impact of the CISG. Disponivel em: <http://www.cisg. law.pace.edu/cisg/biblio/basedow.html> Acesso em: 13. ago. 2013. não implica resolução contratual. Abordando essas situações, há dois casos bastante interessantes, ambos julgados na Alemanha, dignos de nota.

O primeiro caso diz respeito a um vendedor alemão e um comprador belga que negociaram $12.600 \mathrm{Kg}$ (doze mil e seiscentos quilogramas) de carne de veado. O contrato estipulava que a carne deveria ser enviada para a cidade de Antuérpia, a $45 \mathrm{~km}$ (quarenta e cinco quilômetros) de Bruxelas, na Bélgica, e que a expedição se daria mediante o pagamento da fatura.

Logo após a conclusão do contrato, o vendedor informado de que parte da carne chegaria de avião em Bruxelas, perguntou ao comprador se ele poderia retirar a mercadoria naquela cidade. Como o comprador se recusou a tomar a mercadoria na cidade de Bruxelas, então o vendedor se ofereceu para entregar a mercadoria na cidade de Antuérpia, dentro do prazo do contrato e reiterou o pedido de pagamento imediato. O comprador não efetuou o pagamento e alegou que o vendedor se recusou a cumprir o contrato no que diz respeito ao local da entrega.

A discussão foi levada ao Tribunal de Apelação de Braunschweig $^{40}$, na Alemanha, o qual ponderou que não era convincente a alegação do comprador de que a proposta do vendedor para que mercadoria fosse retirada em local diferente do previsto em contrato caracterizava recusa ao cumprimento, tomando-se em conta a interpretação que lhe conferiria uma pessoa razoável em circunstâncias semelhantes nos termos do art. $8^{\circ}$ da CISG.

O Tribunal entendeu que o comprador não manifestou interesse em cumprir o contrato e decidiu que o vendedor tinha direito a perdas diretas, despesas com armazenamento da carne e lucros cessantes.

Nesse caso, verifica-se que o vendedor propôs uma alteração no local de entrega da mercadoria com a qual o comprador poderia ter concordado ou não. Evidentemente que o fato de o comprador retirar a mercadoria em Bruxelas ao invés de Antuérpia, acabaria por lhe transferir um custo que antes pertencia ao vendedor, de maneira que se as partes não chegassem a um consenso quanto a essa recomposição, poderiam ter submetido a causa a julgamento.

40 ALEMANHA. Tribunal de Apelação de Braunschweig. Julgamento em: 28, de outubro de 1999. Disponível em: <http:// cisgw3.law.pace.edu/cases/991028g1.html> Acesso em: 14 ago. 2013. 
Entretanto, a forma como o comprador conduziu a situação, dando o contrato por resolvido e recusandose ao pagamento do preço, fez com que, ao invés de ter um direito a reparação de danos, ele incidisse em inadimplemento substancial perante o vendedor sendo condenado ao pagamento de indenização.

Situação bastante diferente, mas que envolve a entrega das mercadorias em local diferente do pactuado, é a que se verifica no caso julgado pelo Superior Tribunal Regional de Oldenburg ${ }^{41}$. O réu Alemão tinha uma relação negocial duradoura com uma empresa dinamarquesa produtora de salmão defumado, a qual adquiria a matéria-prima da autora do processo, uma empresa norueguesa.

Devido a dificuldades econômicas da empresa dinamarquesa, o réu contatou diretamente a autora para lhe vender certa quantidade de salmão cru para processamento pela empresa dinamarquesa.

O local de entrega estabelecido em contrato era um armazém público à disposição do comprador. Contudo, a autora não entregou a mercadoria no local estabelecido em contrato, mas sim no local de negócios da empresa dinamarquesa, como indicado nas faturas às quais o réu alemão não se havia oposto.

Efetuada a entrega do produto, a empresa dinamarquesa faliu e o réu não recebeu qualquer salmão cru ou defumado. A autora ajuizou a ação para receber o preço do salmão cru que o réu se recusava a pagar alegando a resolução do contrato. O Tribunal entendeu que não assistia razão ao réu e lhe negou o direito a resolução do contrato sob o argumento de que a autora não o privou daquilo que tinha direito por força do contrato, isto é, não houve inadimplemento essencial nos termos do art. 25 da CISG.

Ademais, considerou que houve aceitação tácita de diferente local de entrega, uma vez que este constava nas faturas emitidas pela autora. O Tribunal ponderou ainda que as mercadorias foram colocadas à disposição do comprador (réu) transferindo-se o risco a ele e julgou procedente o pedido do autor condenando o réu ao pagamento do preço.

Esse caso é especialmente intrigante porque o comprador não teve efetivamente acesso às mercadorias

41 ALEMANHA. Superior Tribunal Regional de Oldenburg. Julgamento em: 22, de setembro de 1998. Disponível em: <http:/ / www.unilex.info $/$ case.cfm?pid $=1 \& d o=$ case $\& i d=506 \&$ step $=$ Abstra ct> Acesso em: 14 ago. 2013. e ainda assim foi condenado a pagar o preço, pois, considerou-se que o risco já havia sido transferido a ele.

Destaque-se que, nesse caso, ao contrário do anterior em que o vendedor apenas propôs a entrega em local diferente do estabelecido em contrato, a entrega foi efetivada em outro local e mesmo assim o tribunal não entendeu tratar-se de um inadimplemento essencial nos termos do art. 25 da CISG.

\subsection{Atraso na entrega das mercadorias}

Não menos delicada que alteração do local de entrega é o tempo da entrega. No que se refere ao atraso na entrega das mercadorias, o Tribunal de München ${ }^{42}$ na Alemanha já manifestou, de forma incidental, que não configura inadimplemento essencial, a menos que o comprador tenha fixado um período adicional de tempo para a entrega e o vendedor o tenha descumprido novamente, nos termos do art. 49(1)b da Convenção.

$O$ caso em que o Tribunal ventilou o assunto envolvia um vendedor italiano e um comprador alemão que acordaram a compra e venda de sapatos, mas como o comprador não pagou o preço, o vendedor entregou apenas parte da quantidade de sapatos encomendada e processou o comprador para obter o preço de compra. O comprador alegou que os bens estavam em desconformidade e pediu indenização por perda de lucro.

Nessa situação o Tribunal de München entendeu que o vendedor tinha direito de exigir o preço do comprador, pois este havia perdido o direito de invocar falta de conformidade por não ter avisado o vendedor tempestivamente. O tribunal rejeitou o de resolução do contrato por parte do comprador, bem como seu pedido de perdas e danos por fixação de preço mercado de acordo com o art. 76 da CISG.

O Tribunal de Apelação de Turku ${ }^{43}$, na Finlândia, também decidiu pela não resolução do contrato em face de atraso na entrega. A situação envolvia um vendedor alemão e um comprador finlandês que firmaram um contrato de compra e venda de alimentos de origem

42 ALEMANHA. Tribunal de Primeira Instância de München. Julgamento em: 20, de fevereiro de 2002. Disponível em: <http:// www.unilex.info $/$ case. $\mathrm{cfm}$ ?pid $=1 \& \mathrm{do}=$ case $\&$ id $=904 \&$ step $=$ Abstra ct>. Acesso em: 14 ago.2013

43 FINLÂNDIA. Tribunal de Apelação de Turku. Julgamento em: 16, de junho de 1995. Disponível em: <http://www.unilex. info $/$ case.cfm?pid $=1 \&$ do $=$ case $\& i d=797 \&$ step $=$ Abstract $>$. Acesso em: 14 ago. 2013. 
animal cuja entrega foi adiada. Segundo o Tribunal, o tempo razoável e usual de entrega nesse ramo de atividade é de 8 semanas, mas a entrega se deu em 14 semanas, de maneira que não considerou o atraso como um inadimplemento essencial do contrato.

Entretanto, há situações em que o atraso na entrega caracteriza inadimplemento essencial. O Supremo Tribunal Regional de Hamburg ${ }^{44}$, na Alemanha, certa vez decidiu que o atraso na entrega de mercadoria configurava inadimplemento essencial.

O caso analisado envolvia a compra e venda de ferro cuja composição deveria conter pelo menos $64 \%$ de molibdênio. Nessa situação era do conhecimento do vendedor que a entrega das mercadorias dentro do prazo era fundamental ao comprador.

Não bastasse isso, o vendedor não deu satisfação ao comprador deixando-o na incerteza acerca do cumprimento ou não do contrato. No caso, o comprador realizou uma compra em substituição e sua indenização foi fixada nos termos do art. 75 da CISG.

Nessa perspectiva, para que um atraso seja classificado como um inadimplemento essencial devese levar em conta uma série fatores que excedem o instrumento contratual em si considerado, passando por uma análise do tipo de mercadoria e das suas condições de mercado, bem com as informações que as partes trocaram entre si durante a relação negocial além da conduta das partes diante da dificuldade encontrada para cumprimento da obrigação.

\subsection{Não conformidade das mercadorias}

A próxima situação a ser considerada é aquela em que se verifica a não conformidade dos bens entregues pelo vendedor, situação que pode ou não conduzir à resolução do contrato conforme o caso. Em 2002 o Superior Regional de Köln ${ }^{45}$, na Alemanha, julgou um caso em que um vendedor italiano e um comprador alemão celebraram um contrato de compra e venda de roupas femininas sazonais de alta qualidade.

44 ALEMANHA. Superior Tribunal Regional de Hamburg. Julgamento: 28, de fevereiro de 1997. Disponível em: < http://www. unilex.info $/$ case.cfm?pid $=1 \& \mathrm{do}=$ case $\& \mathrm{id}=291 \&$ step $=$ Abstract $>$. Acesso em: 14 ago. 2013.

45 ALEMANHA. Superior Tribunal de Köln. Julgamento em: 14, de outubro de 2002. Disponível em: <http://www.unilex.info/ case.cfm?pid $=1 \& \mathrm{do}=$ case $\&$ id $=860 \&$ step $=$ Abstract $>$. Acesso em: 14 ago. 2013.
Entretanto, no ato de conferência o comprador observou que um número significativo de peças de roupas apresentava deformidade e os tamanhos se desviavam significativamente (até três números) da escala regular tornando-as insuscetíveis de venda. O comprador imediatamente reclamou da não conformidade dos bens ao vendedor, informandolhe não estar mais interessado em novas entregas e solicitando a devolução do pagamento parcial realizado.

O Tribunal considerou legítima a resolução do contrato por parte do comprador nos termos do art. 49(1)(a) da CISG e lhe concedeu o direito de ser reembolsado pelo pagamento realizado. Contudo, o Tribunal ressaltou que no sistema da Convenção, a resolução do contrato é remédio excepcional devendose dar preferência à redução do preço e à fixação de danos, nos termos dos artigos 50 e 45(1)(b) da CISG respectivamente.

Ademais, ponderou-se que mesmo uma substancial não conformidade dos bens não equivale a uma violação fundamental capaz de declarar o contrato resolvido se o vendedor estiver disposto a reparar os bens e desde que isso não cause transtornos irrazoáveis ao comprador.

Observe-se que o contrato tinha por objeto a aquisição de roupas sazonais, isto é, de determinada época do ano. Considerando que as coleções se dividem, em geral, em primavera-verão e outono-inverno, o comprador dispunha de apenas seis meses para liquidar o produto comprado. Diante dessa informação é possível entender porque o Tribunal julgou legítima a resolução do contrato, pois como explicam Schelechtriem e Butler $^{46}$, se o contrato tem como objeto mercadorias sazonais, "um atraso geralmente resultará em uma quebra fundamental do contrato, de modo que este contrato pode ser imediatamente resolvido (sem tempo adicional para a entrega) ".

Ademais, à luz do que foi elucidado no tópico referente à privação substancial e legítima expectativa, se o contrato tinha por objeto roupas femininas de alta qualidade, é evidente que o defeito grosseiro que tornou as peças insuscetíveis de venda privou o comprador daquilo que ele legitimamente esperava do contrato.

46 SCHELECHTRIEM, Peter; BUTLER, Petra. UN law on the international sales: the UN Convention on the Internacional Sale of Goods. Wellington, Springer. p. 99. 
Contudo, como bem ressaltado na decisão do Tribunal de Köln ${ }^{47}$ não é em todos os casos que o defeito enseja a resolução do contrato. A título de exemplo cumpre mencionar o caso levado a julgamento perante o Superior Tribunal Regional de Frankfurt ${ }^{48}$, na Alemanha, em 1994, em que um comprador alemão e um vendedor italiano celebraram um contrato para venda de calçados femininos. O comprador não pagou parte do preço alegando que o vendedor não entregou a mercadoria no prazo e que esta apresentava defeitos, então o vendedor ajuizou ação para obter o saldo do preço.

O Tribunal afirmou que para o comprador declarar resolvido o contrato por entrega de mercadoria a destempo tem que fixar um período adicional para o desempenho do vendedor, conforme art. 49(1)(b) da CISG. Em relação à alegação de não conformidade dos bens, o Tribunal sustentou que somente pode caracterizar inadimplemento essencial quando os defeitos impedem o comprador de fazer uso razoável dos bens.

No caso em questão o comprador se restringiu a alegar que os sapatos apresentavam defeitos e que foram produzidos com material diferente daquele acordado, entretanto, não comprovou que os sapatos não poderiam ser utilizados em decorrência de tais defeitos. O pedido do vendedor foi julgado procedente condenando-se o vendedor ao pagamento do saldo do preço acrescido de juros de $10 \%$.

Frise-se que na ocorrência das roupas femininas, o comprador explicou detalhadamente o defeito e sustentou que, devido a sua ocorrência as peças eram invendáveis. Já o comprador dos sapatos limitou-se a afirmar que os sapatos apresentavam defeitos, mas não demonstrou a impossibilidade de vendê-los.

Em outra situação que envolvia calçados, dessa vez entre um comprador esloveno e um vendedor italiano, o julgamento foi favorável ao comprador ${ }^{49}$. Após a assinatura do contrato o comprador esloveno pagou

47 ALEMANHA. Superior Tribunal de Köln. Julgamento em: 14, de outubro de 2002. Disponível em: <http://www.unilex.info/ case. $\mathrm{cfm}$ ?pid $=1 \& \mathrm{do}=$ case $\&$ id $=860 \&$ step $=$ Abstract $>$. Acesso em: 14 ago. 2013.

48 ALEMANHA. Superior Tribunal Regional de Frankfurt. Julgamento em: 18, de janeiro de 1994. Disponível em: <http:// www.unilex.info $/$ case. $\mathrm{cfm}$ ?pid $=1 \& \mathrm{do}=$ case $\& \mathrm{id}=40 \&$ ste $\mathrm{p}=$ Abstra ct>. Acesso em: 14 ago. 2013.

49 ITÁLIA. Tribunal de Forli. Julgamento em: 9, de dezembro de 2008. Disponível em: <http://www.globalsaleslaw.org/content/ api/cisg/display.cfm?test=1729>. Acesso em: 27 maio 2014. o preço acordado, porém, ao realizar inspeção nos produtos recebidos constatou que a maioria dos itens apresentavam defeitos que os tornavam insuscetíveis de venda.

O comprador comunicou o vendedor italiano que se ofereceu para substituir os bens defeituosos, mas tal substituição não era possível por condições atinentes ao mercado esloveno, de maneira que o comprador solicitou a restituição do valor pago.

Como o vendedor se opôs a restituição do valor, o comprador ajuizou a demanda no Tribunal de Forli na Itália. O Tribunal julgou procedente a pretensão do comprador e condenou o vendedor a restituir os valores pagos. Nesse caso o Tribunal ponderou que houve um inadimplemento essencial, dado que apenas 10\% dos bens entregues atendiam as condições especificadas no contrato.

Entretanto, é importante recordar que nem sempre os tribunais consideram a violação contratual um inadimplemento essencial. Veja-se o negócio realizado entre um comprador Chinês e um vendedor Japonês de polipropileno em que o contrato previa condições pormenorizadas quanto à embalagem e inspeção no porto de destino ${ }^{50}$.

O comprador, ao realizar a inspeção, encontrou significativa quantidade de mercadorias danificadas devido à embalagem inadequada. Nesse caso havia ocorrido uma modificação quanto ao porto de destino, o que levou o vendedor a argumentar que o comprador não inspecionou as mercadorias no porto de destino originalmente previsto.

Analisando a situação, a Comissão Internacional de Arbitragem Comercial da China (CIETAC) decidiu que o vendedor violou o contrato quando não embalou adequadamente os produtos e considerou que os danos causados eram perfeitamente previsíveis. $\mathrm{O}$ vendedor foi condenado a compensar o prejuízo sofrido pelo comprador, incluindo perda de bens, parte da perda de lucros, juros e outros custos razoáveis, mas não foi declarado inadimplemento essencial do contrato.

Ainda quanto à conformidade das mercadorias, é importante mencionar que a descrição pormenorizada das características técnicas da mercadoria no contrato

50 CHINA. Comissão Internacional de Arbitragem Comercial da China (CIETAC). Julgado em: 23, de julho de 1997. Disponível em: <http://www.globalsaleslaw.org/content/api/cisg/display. cfm?test=1895>. Acesso em 27 maio 2014. 
pode ser decisiva para uma futura atribuição de indenização.

Um caso envolvendo uma compradora Coreana e uma vendedora espanhola ilustra bem a importância da descrição ${ }^{51}$. Trata-se de situação em que a compradora depois de ver uma amostra do material produzido pela vendedora declarou resolvido o contrato por considerar que a mercadoria não atendia os padrões acordados.

A compradora fez uma compra em substituição de outra empresa e ingressou com pedido de perdas e danos pela diferença contra a vendedora espanhola. O Tribunal Distrital Central de Seul, ao apreciar a questão julgou improcedente o pedido por considerar que não havia prova da exigência de uma qualidade específica afirmando que nesses casos as mercadorias são consideradas desconformes apenas quando não são adequadas para os fins aos quais normalmente se destinam.

A análise das decisões mencionadas acima evidencia que as especificidades do caso concreto permitem precisar se há ou não um inadimplemento essencial, porém, este não é necessário para que se condene a parte que violou o contrato a perdas e danos.

\section{Dos danos recuperáveis perante o artigo 74}

A análise das decisões envolvendo a aplicação da CISG revela uma tendência das partes requererem aos tribunais o reconhecimento da resolução do contrato, revelando uma subutilização do instituto das perdas e danos em casos de inadimplemento não essencial. Em outras palavras, a parte lesada busca a resolução do contrato argumentando pelo inadimplemento essencial mesmo quando isso não é razoável como caso da entrega da carne em Bruxelas, ou no caso dos defeitos dos sapatos femininos.

Abusos de direito à parte, é de se convir que a situação fica ainda mais complicada porque as mesmas violações que em alguns casos caracterizam inadimplemento essencial e conduzem à resolução do contrato, em outros casos não têm o mesmo efeito dependendo, em grande medida, das especificidades de cada situação e das provas produzidas pelas partes.

Assim, se para alguns contratos específicos referentes a determinadas mercadorias inseridas

51 KOREA. Corte Distrital Central de Seoul. Julgado em: 5 de dezembro de 2008. Disponível em: < http://cisgw3.law.pace.edu/ cases/081205k3.html\#uab>. Acesso em: 27 maio 2014. em certos mercados o atraso na entrega não priva substancialmente o comprador daquilo que lhe era legítimo esperar do contrato, em contrapartida, em outros casos, isso é suficiente para tornar o inadimplemento totalmente desinteressante para o comprador.

Nessa perspectiva, o contexto no qual o caso concreto se insere e as provas produzidas pelas partes são essenciais para a caracterização do inadimplemento essencial que autoriza a resolução do contrato. Contudo, partindo do princípio que a violação de qualquer obrigação contratual pode conduzir a um pedido de indenização, quais seriam as perdas e os danos efetivamente recuperáveis de acordo com esse artigo?

Segundo John GOTANDA ${ }^{52}$, costuma-se classificar os danos recuperáveis sob o amparo da CISG em três categorias, são elas: perdas diretas, danos incidentais e danos consequentes.

\subsection{Perda direta ou perda por incumprimento}

A perda direta segundo John GOTANDA ${ }^{53}$ corresponde à perda de valor resultante da violação apurada por meio da diferença entre o valor do desempenho que deveria ter sido recebido e o que efetivamente foi recebido pela parte lesada.

Ingeborg Schewenzer ${ }^{54}$ prefere utilizar o termo "perda por incumprimento" (non-performance loss) ao termo "perda direta", por considerá-lo mais adequado ao caráter universal da CISG, uma vez que aquele abrange o que as leis domésticas costumam chamar de perda direta sem, entretanto, considerar os mecanismos que os ordenamentos nacionais utilizam para distinguilas das perdas indiretas.

Para elucidar o conceito do que Schwenzer ${ }^{55}$ define como "perda por incumprimento", a autora afirma

52 GOTANDA, John. Section II, Damages. In: KRÖLL, Stefan; MISTELIS, Loukas; VISCASSILAS, Pilar Perales. UN Convention on Contracts for the International Sale of Goods (CISG). München: C.H. Beck, 2011. p. 995.

53 GOTANDA, John. Section II, Damages. In: KRÖLL, Stefan; MISTELIS, Loukas; VISCASSILAS, Pilar Perales. UN Convention on Contracts for the International Sale of Goods (CISG). München: C.H. Beck, 2011. p. 995.

54 SCHWENZER, Ingeborg; HACHEM, Pascal; KEE, Christopher. Global sales and contract law. Oxford: Oxford University Press, 2012. p. 611.

55 SCHWENZER, Ingeborg. Section 11, Damages. In: SCHLECHTRIEM, Peter; SCHWENZER, Ingeborg. Commentary on the UN Convention on the International Sale of Goods (CISG). 3. ed. 
tratar-se da perda verificada quando o comprador não recebe uma contraprestação adequada ao preço pago. Se o contrato foi resolvido, a perda direta é calculada segundo o artigo 75 e 76, porém, se o contrato não foi resolvido os danos são calculados de acordo com o art. 74 tomando-se por base os custos de uma transação substituta.

No caso de as mercadorias terem sido entregues com defeito, o dano consiste na diferença entre o valor dos bens defeituosos e o valor que eles teriam se estivessem em conformidade com o pactuado ${ }^{56}$. Se o defeito dos bens é sanável, a perda por incumprimento pode ser calculada de acordo com as despesas necessárias fazêlo. ${ }^{57}$

Contudo, a explicação mais didática ao que se compreende por perda direta pode ser atribuída a Djakhongir Saidov ${ }^{58}$, a qual segue em tradução livre:

Uma parte no contrato, muitas vezes, incorre em despesas que constituem parte do seu desempenho do contrato na expectativa de que elas serão recuperadas a partir do valor recebido do desempenho da outra parte. Se, porém, essa outra parte não o fizer, essas despesas podem, totalmente ou em parte, acabarem sendo desperdiçadas, causando perdas.

O conceito acima evidencia que as perdas diretas correspondem àquelas despesas que na ausência de violação seriam consideradas como normais do negócio. De acordo com Saidov ${ }^{59}$, o critério para definir as perdas diretas consiste em verificar se a despesa realizada pela

Oxford: Oxford University Press, 2010. p. 1006.

56 SCHWENZER, Ingeborg. Section 11, Damages. In: SCHLECHTRIEM, Peter; SCHWENZER, Ingeborg. Commentary on the UN Convention on the International Sale of Goods (CISG). 3. ed. Oxford: Oxford University Press, 2010. p. 1006.

57 SCHWENZER, Ingeborg. Section 11, Damages. In: SCHLECHTRIEM, Peter; SCHWENZER, Ingeborg.. Commentary on the UN Convention on the International Sale of Goods (CISG). 3. ed. Oxford: Oxford University Press, 2010. p. 1007.

58 SAIDOV, Djakhongir. The law of damages in the international sale of goods: the CISG and other Internations Instruments. Oxford: Hart Publishing, 2008, p. 40. Tradução livre de: "A party to the contract often incurs expenses which constitute part of its performance of (or preparation to perform) the contract in the expectation that they will be recouped from the value received from the other party's performance. If, however, that other party fails to do so, these expenses may, wholly or in part, turn out to be wasted, thereby causing loss."

59 SAIDOV, Djakhongir. The law of damages in the international sale of goods: the CISG and other internations instruments. Oxford: Hart Publishing, 2008. p. 41. parte possui "essencial dependência" com a execução do contrato. Constatando-se essa dependência, a perda deve ser classificada como direta.

Como exemplo pode se citar a decisão proferida pelo Tribunal de Apelação de $\mathrm{Hamm}^{60}$, na Alemanha, em 1978, quando ainda vigorava a Lei Uniforme para Venda Internacional de Mercadorias (Uniform Law for the International Sale of Goods - ULIS), decidiu que o comprador deveria indenizar o vendedor que fabricou amostras dos produtos, bem como, após a conclusão do contrato, criou ferramentas para a fabricação das válvulas a serem entregues ao comprador.

\subsection{Danos incidentais}

Têm-se como danos incidentais aqueles verificados quando a parte lesada se obriga a incorrer em despesas adicionais para evitar novas perdas. ${ }^{61}$ A recuperação das perdas incidentais que não está explicitamente mencionada no artigo 74 abrange, por exemplo, despesas com preservação e armazenamento de bens, custos adicionais de transporte ${ }^{62}$, custos de modificação do produto para atender às necessidades de um novo comprador, custos com transação substituta ${ }^{63}$, entre outros.

Saidov $^{64}$ aponta para um fenômeno interessante em relação a esses danos incidentais verificado nos tribunais. Segundo ele, além do critério da razoabilidade, isto é, a despesa incorrida para evitar outras perdas deve ser de um valor razoável, tem-se defendido que a despesa incorrida tem que ser necessária ou inevitável.

Tomando em conta a inevitabilidade da despesa, a Comissão Internacional Chinesa de Arbitragem

60 ALEMANHA. Tribunal de Apelação de Hamm. Julgado em: 23, de março de 1978. Disponível em: < http:/ / cisgw3.law.pace.edu/ cases/780323g1.html>. Acesso em: 19 set. 2013.

61 GOTANDA, John. Section II, Damages. In: KRÖLL, Stefan; MISTELIS, Loukas; VISCASSILAS, Pilar Perales. UN Convention on Contracts for the International Sale of Goods (CISG). München: C.H. Beck, 2011. p. 996.

62 SCHWENZER, Ingeborg. Section 11, Damages. In: SCHLECHTRIEM, Peter; SCHWENZER, Ingeborg.. Commentary on the UN Convention on the International Sale of Goods (CISG). 3. ed. Oxford: Oxford University Press, 2010. p. 1009.

63 SAIDOV, Djakhongir. The law of damages in the international sale of goods. the CISG and other internationsl instruments. Oxford: Hart Publishing, 2008. p. 44-45.

64 SAIDOV, Djakhongir. The law of damages in the international sale of goods: the CISG and other internationsl instruments. Oxford: Hart Publishing, 2008. p. 45. 
Econômica e Comercial (CIETAC) ${ }^{65}$ obrigou o vendedor que falhou com a entrega a compensar o comprador quanto ao valor que este teve que desembolsar a título de indenização ao subcomprador.

Existe uma polêmica se os custos de litígio e os custos com advogado incorridos por causa de uma violação seriam recuperáveis ${ }^{66}$ a título de perdas incidentais. De acordo com Djakhongir Saidov o dissenso se justifica porque segundo ele não há uniformidade de tratamento quer no âmbito das leis domésticas, quer no da arbitragem internacional. ${ }^{67}$

Saidov ${ }^{68}$ afirma que os argumentos pela recuperação dos custos de litígio e honorários advocatícios decorrem de uma leitura simples do artigo 74, segundo a qual, a parte lesada somente incorre em tais custos em razão do incumprimento. Para sustentá-lo com mais vigor, lançam-se mão dos princípios da reparação integral e da proteção da confiança.

De outro vértice, tem-se sugerido que a recuperação dos custos de litígio e honorários de advogado é matéria que foge ao âmbito de aplicação da Convenção porque a distribuição desses custos é assunto de ordem processual que deve ser deixada para lei doméstica aplicável, uma vez que a Convenção se destina a regular os contratos e não a matéria processual.

Foi sob esse argumento que a Corte Federal de Apelação dos Estados Unidos da América da $7^{\mathrm{a}}$ Seção cassou a decisão de primeira instância que condenou a ré Lenell Cooky Company ao pagamento dos honorários advocatícios à autora Zapata Hermanos Sucesores S.A ${ }^{69}$.

A empresa mexicana forneceu à indústria estadunidense latas para embalar biscoitos, mas não recebeu a maior parte do pagamento pelos produtos

65 CHINA. Comissão Internacional Chinesa de Arbitragem Econômica e Comercial (CIETAC) Disponível em: <http://cisgw3. law.pace.edu/cases/960314c1.html>. Acesso em: 20 set. 2013.

66 SAIDOV, Djakhongir. The law of damages in the international sale of goods: the CISG and other internationsl instruments. Oxford: Hart Publishing, 2008. p. 50.

67 SAIDOV, Djakhongir. The law of damages in the international sale of goods: the CISG and other internationsl instruments. Oxford: Hart Publishing, 2008. p. 50.

68 SAIDOV, Djakhongir. The law of damages in the international sale of goods: the CISG and other internationsl instruments. Oxford: Hart Publishing, 2008. p. 50.

69 ESTADOS UNIDOS DA AMÉRICA. Corte Federal de Apelação da $7^{\text {a }}$ Seção. Julgamento em: 19, de novembro de 2002. Disponível em: <http://cisgw3.law.pace.edu/cases/021119u1. html>. Acesso em: 28. mai. 2014. fornecidos. Diante disso, ingressou com a ação da qual saiu vencedora e obteve, em primeira instância, a condenação da Maurice Lenell ao pagamento dos honorários de advogado gastos com a ação.

A Corte Federal de Apelação reverteu o julgamento sustentando que a Convenção trata do direito material dos contratos e não de procedimento, o qual fica sujeito à aplicação da lei doméstica, no caso, a lei processual dos Estados Unidos da América que prevê que o vencedor arca com suas próprias despesas de litígio.

Essa última opinião, de que os custos de litígio e os honorários de advogado não são recuperáveis perante a Convenção, é a que tem prevalecido segundo Schwenzer ${ }^{70}$ tornando-se recomendável às partes, mediante cláusula contratual, estabelecer a quem eventualmente compete o pagamento desses custos, pois, se assim não o fizerem, isso será definido pela lei doméstica aplicável ou por meio das regras arbitrais.

No que se refere aos custos pré-litígio, SCHWENZER ${ }^{71}$ afirma ser prevalente o entendimento de que estes são recuperáveis a título de danos incidentais, principalmente, aqueles relacionados à mitigação do dano. Haveria, entretanto, custos prélitígio não recuperáveis entre os quais se enquadrariam os custos de análise provisória da situação jurídica e de análise do possível resultado de quaisquer litígios e negociações.

Schwenzer ${ }^{72}$ também sustenta que custos agência de cobrança e não estariam albergados pelo art. 74 da CISG, todavia, é importante mencionar que Alisson Butler ${ }^{73}$ discorda desse entendimento e inclui entre as perdas recuperáveis sob o art. 74 da CISG os custos com agência de cobrança e os custos com advogado no exterior.

\subsection{Danos consequentes}

70 SCHWENZER, Ingeborg. Section 11, Damages. In: SCHLECHTRIEM, Peter; SCHWENZER, Ingeborg. Commentary on the UN Convention on the International Sale of Goods (CISG). 3. ed. Oxford: Oxford University Press, 2010. p. 1010.

71 SCHWENZER, Ingeborg. Section 11, Damages. In: SCHLECHTRIEM, Peter; SCHWENZER, Ingeborg. Commentary on the UN Convention on the International Sale of Goods (CISG). 3. ed. Oxford: Oxford University Press, 2010. p. 1012.

72 SCHWENZER, Ingeborg. Section 11, Damages. In: SCHLECHTRIEM, Peter; SCHWENZER, Ingeborg. Commentary on the UN Convention on the International Sale of Goods (CISG). 3. ed. Oxford: Oxford University Press, 2010. p. 1012.

73 BUTLER, Allisson E. A practical guide to the CIS G: negotiations through litigation. Disponível em: <http://www.cisg.law.pace.edu/ cisg/biblio/butler6.html >. Acesso em 14 maio 2013. 
Além das perdas diretas e danos incidentais, a doutrina aponta a existência dos danos consequentes compreendidos como aquelas perdas adicionais para além das causadas pelo incumprimento em si. Os danos consequentes incluem, principalmente, a responsabilidade do inadimplente perante terceiros decorrente da violação. ${ }^{74}$

Assim, se um vendedor deixou de entregar um produto ou entregou-o com defeito e o comprador firmou um contrato subsequente de fornecimento daquilo que fabricaria utilizando o produto adquirido no qual assumiu uma multa por atraso esta pode ser cobrada do fornecedor que não cumpriu sua obrigação. ${ }^{75}$

É controvertida a possibilidade de se reclamarem danos por morte ou lesões pessoais a terceiros decorrentes da violação contratual uma vez que a Convenção em seu artigo $5^{\circ}$ ressalva sua não aplicação à responsabilidade do vendedor pela morte ou lesões corporais causadas pelas mercadorias a quem quer que seja.

Muito embora exista essa previsão, Ingeborg Schwenzer ${ }^{76}$ aponta para uma tendência crescente em se admitir a recuperação de danos causados por mercadorias adquiridas mediante negócios regulados sob a Convenção de Viena como parte dos prejuízos financeiros do comprador.

Há um caso emblemático envolvendo reclamação de danos por lesão corporal e morte de terceiros julgado pelo Tribunal de Apelações de Düsseldorf ${ }^{77}$. No caso, o comprador, cuja empresa localizava-se em Krefeld, Alemanha, adquiriu uma máquina de corte do réu vendedor localizado em Indiana, Estados Unidos. A máquina de corte foi instalada numa unidade Russa de processamento de lâminas para mobiliário.

74 SCHWENZER, Ingeborg. Section 11, Damages. In: SCHLECHTRIEM, Peter; SCHWENZER, Ingeborg. Commentary on the UN Convention on the International Sale of Goods (CISG). 3. ed. Oxford: Oxford University Press, 2010. p. 1012.

75 SCHWENZER, Ingeborg. Section 11, Damages. In: SCHLECHTRIEM, Peter; SCHWENZER, Ingeborg. Commentary on the UN Convention on the International Sale of Goods (CISG).3. ed. Oxford: Oxford University Press, 2010. p. 1012.

76 SCHWENZER, Ingeborg. Section 11, Damages. In: SCHLECHTRIEM, Peter; SCHWENZER, Ingeborg. Commentary on the UN Convention on the International Sale of Goods (CISG).3. ed. Oxford: Oxford University Press, 2010. p. 1012.

77 ALEMANHA. Corte de Apelação de Düsseldorf. Julgado em: 02, de julho de 1993. Disponível em: < http://cisgw3.law.pace. edu/cases/930702g1.html> Acesso em: 16 maio 2013.
Depois de ser colocada em operação, a máquina causou um acidente que levou um operário à morte $\mathrm{e}$ lesionou outro. Então, o subcomprador russo exigiu em juízo a reparação da máquina defeituosa, e o comprador processou o vendedor para recuperar os custos da reparação.

O comprador também requereu que o Tribunal declarasse que o vendedor era obrigado a indenizar o comprador contra todos os danos reclamados pelo russo subcomprador a respeito do acidente em discussão. $\mathrm{O}$ Tribunal decidiu que a obrigação do terceiro decorreu de defeitos no produto vendido e que a indenização de tal obrigação é abrangida pelos danos da CISG.

No que se refere aos custos legais, judiciais ou extrajudiciais, incorridos pelo promissário em litígios com terceiros, estes estariam abrangidos pelo art. 74 da CISG e podem ser recuperados do promitente ${ }^{78}$ a título de danos consequentes, como a propósito decidiu a Corte do Distrito de Berlin ${ }^{79}$. Trata-se de um caso em que um comprador diante de defeitos apresentados no veículo revendido a um consumidor francês teve que retomar o veículo e reembolsá-lo pelo preço da compra.

Como o comprador teve que contratar um advogado francês, exigiu na ação de reparação de danos contra o vendedor que o Tribunal o condenasse a reembolsar este custo com advogacia estrangeira, uma vez que o veículo apresentava defeitos e o vendedor havia sido tempestivamente informado disso.

Ainda dentro do que se compreende por danos consequentes estaria aquele referente à perda de reputação ou perda do renome comercial (loss of reputation, loss of goodwill) sob qual circunda a discussão se detém natureza pecuniária ou não.

Schwenzer ${ }^{80}$ defende o caráter pecuniário desta perda, uma vez que o renome comercial tem uma inegável importância econômica, ainda que o cálculo e prova necessária sejam incertos e controversos.

78 SCHWENZER, Ingeborg. Section 11, Damages. In: SCHLECHTRIEM, Peter; SCHWENZER, Ingeborg. Commentary on the UN Convention on the International Sale of Goods (CISG). 3. ed. Oxford: Oxford University Press, 2010. p. 1012.

79 ALEMANHA. Corte do Distrito de Berlin. Julgado em: 13, de setembro de 2006. Disponível em: <http://cisgw3.law.pace.edu/ cases/060913g1.html> Acesso em: 16. jun. 2013.

80 SCHWENZER, Ingeborg. Section 11, Damages. In: SCHLECHTRIEM, Peter; SCHWENZER, Ingeborg. Commentary on the UN Convention on the International Sale of Goods (CISG).3. ed. Oxford: Oxford University Press, 2010. p. 1013. 
Djakhongir Saidov ${ }^{81}$, que também defende o caráter pecuniário do dano ao renome, chega a afirmar que os pedidos de condenação são frequentemente rejeitados porque os autores falham ao provar o seu dano, uma vez que sob a Convenção reconhece-se o padrão probatório da 'razoável certeza'. Ademais, haveria a necessidade de, inicialmente, se demonstrar a existência da reputação ou do renome comercial para depois provar os danos que a violação contratual lhe causou.

A importância de se demonstrar a existência da reputação é reforçada pelo caso Flippe Christian versos Sarl Douet Sport Collections julgado em 19 de janeiro de 1998 pelo Tribunal de Comércio de Besaçon ${ }^{82}$. O comprador, promotor de um clube de judô sueco, adquiriu do vendedor 69 agasalhos infantis e 29 agasalhos para adultos.

A mercadoria foi revendida aos membros do clube de judô, os quais reclamaram que após a lavagem dos agasalhos verificou-se um encolhimento entre 6 e 8 centímetros nas peças. Tal fato pode, em certa medida, ter afetado o renome do clube de judô, entretanto, o pedido de indenização por danos ao renome foi rejeitado pelo tribunal, favorecendo-se o réu que argumentou que o comprador não era comerciante.

Como possíveis provas dos danos à reputação ou ao renome, Saidov ${ }^{83}$ sugere a apresentação dos registros demonstrando a diferença entre o volume de vendas e o nível de lucros atingidos antes e depois do dano, testemunhas que deponham sobre a existência de danos à reputação ou que atestem a dependência do negócio da entrega dos bens pelo vendedor, ou ainda depoimentos de ex-clientes e outras testemunhas que possam indicar que a atividade empresarial foi encerrada por causa dos das entregas defeituosas. Por fim, esse autor indica que a própria perda de lucro pode ser usada como indício do dano ao renome comercial, entranto ressalta que ela sozinha pode não conduzir a essa conclusão.

81 SAIDOV,Djakhongir. Damages to Business Reputation and Goodwill. In: SAIDOV, Djakhongir; CUNNINGTON, Ralph. Contract damages: domestic and international perspectives. Oxford: Hart Publishing, 2008. p. 403.

82 FRANÇA. Tribunal de Comércio de Besançon. Julgado em: 19, de janeiro de 1998. Disponível em: <http://www.unilex.info/ case.cfm? pid $=1 \&$ id $=416 \& \mathrm{do}=$ case $>$ Acesso em: 23 maio 2013.

83 SAIDOV, Djakhongir. Damages to Business Reputation and Goodwill. In: SAIDOV, Djakhongir; CUNNINGTON, Ralph. Contract damages: Domestic and international perspectives. Oxford: Hart Publishing, 2008. p. 404-405.
Além das dificuldades de provar o dano à reputação, bem como promover o respectivo cálculo, John Gotanda ${ }^{84}$ aponta como dificuldade a fluidez do termo reputação comercial que pode significar desde um relacionamento positivo com os consumidores, até a habilidade de a empresa obter lucros acima do normal.

Ciente da dificuldade conceitual em torno do conceito de reputação comercial (goodwill), o Conselho Consultivo da CISG, ao lançar mão do parecer número 6 no qual define diretrizes para o cálculo dos danos sob o art. 74 da CISG, enfatiza que a perda de renome comercial é o "declínio da reputação empresarial ou da imagem comercial, quantificada pela retenção de clientes e que alternativamente, a perda da reputação comercial tem sido definida como a diminuição do valor de um interesse comercial” ${ }^{\$ 5}$.

Existe polêmica também quanto à possibilidade de se exigir reparação de perdas não pecuniárias, as quais não são expressamente excluídas pela CISG. ${ }^{86} \mathrm{~A}$ opinião prevalente é a de que a Convenção só admite a recuperação dos danos materiais ${ }^{87}$, estando excluídos os danos por dor e sofrimento. ${ }^{88}$

De acordo com Peter Schlechtriem ${ }^{89}$ os autores que sustentam a reparabilidade dos danos morais à égide da CISG, o fazem com intuito de proteger a reputação comercial. Todavia, o autor considera um equívoco classificar o dano ao renome como moral e alerta

84 GOTANDA, John. Section II, Damages. In: KRÖLL, Stefan; MISTELIS, Loukas; VISCASSILAS, Pilar Perales. UN Convention on Contracts for the International Sale of Goods (CISG). München: C.H. Beck, 2011. p. 1008.

85 CISG Advisory Council Opinion n ${ }^{\circ}$ 6. Calculation of damages under CISG article 74. Disponível em: <http://cisgw3.law.pace.edu/ cisg/CISG-AC-op6.html> Acesso em: 06 jun. 2013. Tradução livre de: "Loss of goodwill also has been defined as a decline in business reputation or commercial image, quantified by the retention of customers. Alternatively, loss of goodwill has been defined as the decrease in the value of a business interest".

86 SCHWENZER, Ingeborg. Section 11, Damages. In: SCHLECHTRIEM, Peter; SCHWENZER, Ingeborg. Commentary on the UN Convention on the International Sale of Goods (CISG). 3. ed. Oxford: Oxford University Press, 2010. p. 1015.

87 GOTANDA, John. Section II, Damages. In: KRÖLL, Stefan; MISTELIS, Loukas; VISCASSILAS, Pilar Perales. UN Convention on Contracts for the International Sale of Goods (CISG). München: C.H. Beck, 2011. p. 1001.

88 SCHWENZER, Ingeborg. Section 11, Damages. In: SCHLECHTRIEM, Peter; SCHWENZER, Ingeborg. Commentary on the UN Convention on the International Sale of Goods (CISG). 3. ed. Oxford: Oxford University Press, 2010. p. 1015.

89 SCHLECHTRIEM, Peter. Non-Material Damages: recovery under the CISG?. Disponível em: <http://www.cisg.law.pace.edu/ cisg/biblio/schlechtriem15.html>. Acesso em: 06 jun. 2013. 
para a existência do parecer número 6 , do Conselho Consultivo da CISG que sedimentou o entendimento de que o artigo 74 não permite a recuperação de perdas imateriais.

Pode-se concluir, portanto, que a CISG não prevê a reparação de danos imateriais, mas que entre esses não estão incluídos os danos ao renome, os quais são considerados materiais. Lembrando que o parecer número 6 do Conselho Consultivo da CISG, orienta que a recuperação das perdas por dano ao renome esteja disponível à parte prejudicada que provar com razoável certeza a perda financeira suportada ${ }^{90}$.

\subsection{Lucros cessantes}

O artigo 74 da CISG inclui entre os danos recuperáveis a perda de lucros, ou lucros cessantes e o faz de forma expressa porque em alguns sistemas jurídicos o termo perda não abrange a categoria dos lucros cessantes ${ }^{91}$.

Diante dessa opção feita pela CISG, autores como SCHWENZER" 92 passaram a afirmar que "enquanto o termo perda dentro do artigo 74 contempla o prejuízo para os ativos existentes ao tempo da conclusão do contrato, a noção de lucro cessante cobre cada aumento no ativo que foi impedido em decorrência da violação".

Ainda segundo o magistério de Schwenzer ${ }^{93}$, os lucros cessantes abrangem o lucro que o comprador teria obtido com a revenda dos produtos e que foi obstado pela quebra contratual do vendedor, bem

90 CISG Advsory Council Opnion n ${ }^{\circ}$ 6. Calculation of damages under CISG article 74. Disponível em: <http://www.cisgac.com/ default.php?ipkCat $=128 \&$ ifkCat $=202 \&$ sid $=202>$ Acesso em: 06 jun. 2013.

91 Comentário sobre o Projeto de Convenção sobre Contratos para a Venda Internacional de Mercadorias elaborado pela Secretaria. Comentário ao art. 74. Disponível em: < http://www.globalsaleslaw. org/index.cfm?pageID=644\#Article $\% 2074>$ Acesso em: 04. set. 2013.

92 SCHWENZER, Ingeborg. Section 11, Damages. In: SCHLECHTRIEM, Peter; SCHWENZER, Ingeborg. Commentary on the UN Convention on the International Sale of Goods (CISG). 3. ed. Oxford: Oxford University Press, 2010. p. 1014. Tradução livre de: "While the term 'loss' within the meaning of Article 74 envisages detriment to the assets existent at the time of the conclusion of the contract, the notion of 'loss of profit' covers every increase in assets which was prevented by the breach."

93 SCHWENZER, Ingeborg. Section 11, Damages. In: SCHLECHTRIEM, Peter; SCHWENZER, Ingeborg. Commentary on the UN Convention on the International Sale of Goods (CISG).3. ed. Oxford: Oxford University Press, 2010. p. 1014. como incluem as perdas resultantes da impossibilidade de manter a atividade empresarial funcionando por conta da violação contratual.

Nessa perspectiva, o lucro de revenda seria uma espécie de lucro cessante a admitir duas formas de cálculo: pela diferença entre o preço do contrato e o preço de revenda ao cliente do comprador; ou pela diferença entre o preço de mercado e o preço do contrato. $^{94}$

O primeiro método foi usado no caso do Papel de Arte ${ }^{95}$ julgado pela Comissão Internacional Chinesa de Arbitragem Econômica e Comercial (CIETAC) em 12 de fevereiro de 1996 no qual um comprador chinês e um vendedor americano celebraram um contrato para compra e venda de papel de arte.

Seguindo os ditames contratuais o comprador emitiu uma carta de crédito irrevogável, mas o vendedor não entregou as mercadorias. Entre os pedidos formulados pelo autor, estavam o pedido de indenização por atraso na entrega e o de recuperação dos custos associados à emissão da carta de crédito ambos rejeitados pelo Tribunal Arbitral.

Contudo, o comprador obteve a recuperação da perda de pagamento, uma vez que em razão da violação contratual perpetrada pelo vendedor o comprador chinês deixou de cumprir o contrato com o seu cliente para quem teve que devolver em dobro o pagamento que havia recebido. O Tribunal também julgou procedente o pedido do comprador pela recuperação dos lucros cessantes calculados como a diferença entre o preço do contrato e o preço de revenda, além de condenar o vendedor a suportar os custos do processo de arbitragem.

Essa diferença entre o preço do contrato e o preço de revenda pode ser calculada de forma estimada como fez Corte de Apelação de Köln, na Alemanha, no caso julgado em 12 de janeiro de 2007 conhecido como caso das embalagens de papelão ${ }^{96}$.

94 RACZYNSKA, Magdalena. Recoverability of the buyer's lost resale profit under CISG. Disponível em: <http://www.njcl.fi/2_2007/ article2.pdf> Acesso em: 16 set. 2013.

95 CHINA. Comissão Internacional Chinesa de Arbitragem Econômica e Comercial (CIETAC). Julgado em: 12, de fevereiro de 1996. Disponível em: < http://cisgw3.law.pace.edu/cases/960212c1. html> Acesso em: 16 set. 2013.

96 ALEMANHA. Corte de Apelação de Köln. Julgado em: 12, de janeiro de 2007. Disponível em: <http://cisgw3.law.pace.edu/ cases/070112g1.html>. Acesso em: 16. set. 2013. 
A compradora alemã e a vendedora checa celebraram contrato de fabricação e fornecimento, pelo prazo de 4 anos, de arquivos em papelão firme. Nesse contrato as partes estipularam volume padrão de negócios, descontos para pagamento antecipado e direito de varejo exclusivo ao comprador em todo território alemão.

Um ano antes do término do contrato, a compradora recusou-se a assinar um termo aditivo em a parte vendedora alterava o foro competente, bem como a lei aplicável ao contrato. Diante disso, o vendedor declarou a resolução imediata do contrato, por carta, em 12 de dezembro de 2002, deixando de fornecer as mercadorias.

O Tribunal de Köln entendeu que a resolução era indevida e condenou a parte vendedora ao pagamento de lucros cessantes à compradora, nos termos da estimativa apresentada por esta. A compradora apresentou uma expectativa de volume de negócios com uma margem de lucro de $30 \%$, dos quais deveriam ser excluídos os custos de revenda estimados em 10\%.

Considerando que havia uma expectativa de negócios no montante de $€ 115.000,00$ (cento e quinze mil euros), cujo volume de negócios efetivamente prestados pelo vendedor foi no importe de $€ 1.444,00$ (mil quatrocentos e quarenta e quatro euros), restando um volume de negócios a serem satisfeitos no montante de $€ 113.556,00$ (cento e treze mil quinhentos e cinquenta e seis euros).

Calculando-se o lucro de 30\% sobre esse último valor, tem-se o equivalente a $€ 34.066,80$ (trinta e quatro mil, sessenta e seis euros e oitenta centavos), dos quais se subtrai os $10 \%$ referentes aos custos de operação, equivalentes a $€ 3.406,68$ (três mil quatrocentos e seis euros e sessenta e oito centavos). Dessa forma os lucros cessantes foram arbitrados em $€ 30.660,12$ (trinta mil seiscentos e sessenta euros e doze centavos).

O segundo método foi aplicado pelo Tribunal de Arbitragem Comercial Internacional da Câmara de Comércio e Indústria da Federação Russa em caso julgado em 27 de maio de $2005^{97}$.

Trata-se de contrato de compra e venda firmado entre um comprador turco e um vendedor russo, em que este não entregou parcela da mercadoria pré-paga

97 RÚSSIA. Tribunal de Arbitragem Comercial Internacional da Câmara de Comércio e Indústria da Federação Russa. Julgado em: 27, de maio de 2005. Disponível em: <http://cisgw3.law.pace.edu/ cases/050527r1.html>. Acesso em: 16. set. 2013. ao comprador que o processou por lucros cessantes. Ao conceder o pedido de lucros cessantes, o tribunal russo tomou por base a taxa de lucro existente no mercado turco, que poderia ser obtida com a revenda das mercadorias e que foi comprovada pelo comprador por meio de documentos.

Contrariando a opinião de Gottanda ${ }^{98}$, que afirma que os lucros cessantes "não precisam ser calculados com precisão matemática" tratando-se de uma estimativa, em todos os casos mencionados anteriormente observa-se que houve uma preocupação com a exatidão dos cálculos.

Corrobora com esse entendimento a decisão do Tribunal de Arbitragem Comercial Internacional da Câmara de Comércio e Indústria da Ucrânia $^{99} \mathrm{em}$ que se reduziram os lucros cessantes do comprador porque se entendeu que este não apresentou cálculos fundamentados da perda de lucros no montante de US\$ 1.700.000,00 (um milhão e setecentos mil dólares).

Nesse caso o Tribunal arbitrou os lucros cessantes em US\$ 897.000,00 (oitocentos e noventa e sete mil dólares) sob o argumento de que este valor consistia na diferença entre o preço de mercado e o preço atribuído em contrato para os bens, subtraindo-se $10 \%$ a título de desvio dos números concretos apresentados pelas partes.

Em síntese, pode-se afirmar ainda que o volume de vendas possa ser estimado, o preço de mercado tem que ser provado com razoável certeza, havendo sim uma preocupação por parte dos Tribunais com a exatidão do cálculo.

\section{0 dano como um conceito em transformação}

Diante do exposto fica evidente que além das dificuldades probatórias enfrentadas por aquele a quem incumbe a demonstração do dano, existem impasses doutrinários sobre aspectos centrais da disciplina de danos.

Se partirmos da concepção tradicional amparada pela teoria do benefício econômico perante a qual um

98 GOTANDA, John. Section II. Damages. In: KRÖLL, Stefan; MISTELIS, Loukas; VISCASSILAS, Pilar Perales. UN Convention on Contracts for the International Sale of Goods (CISG). München: C.H. Beck, 2011. p. 998.

99 UCRÂNIA. Tribunal de Arbitragem Comercial Internacional da Câmara de Comércio e Indústria da Ucrânia. 2005. Case n 48. Disponível em: <http://cisgw3.law.pace.edu/cases/050000u5. html>. Acesso em: 16 set. 2013. 
contrato é sempre firmado no intuito de se obter uma vantagem financeira calculável monetariamente e que, consequentemente, a disciplina dos danos deve proteger a posição econômica da parte lesada, corremos o risco de tornar irrecuperáveis as perdas que não aparecem no balanço econômico da parte lesada, que em geral são as perdas consideradas não pecuniárias ${ }^{100}$.

Schewenzer e Hachem ${ }^{101}$ apresentam três exemplos interessantes para reflexão da atual perspectiva de danos:

\begin{abstract}
Hipótese 1: suponha que o comprador é transportador comercial que comprou 10 caminhões para transporte. Se eles não forem entregues no prazo, o comprador terá que alugar caminhões substitutos para exercer sua atividade. Os custos de aluguel serão unanimemente reconhecidos como perda pecuniária sob o princípio do benefício econômico. No entanto, vamos mudar um pouco os fatos. O comprador não é mais um transportador profissional, mas sim uma organização não governamental (ONG) transportando comida para o Sahel. Como não existem caminhões substitutos a serem alugados lá, eles são necessários, não ocorrendo perda nesse sentido.
\end{abstract}

Hipótese 2: Suponha que uma empresa Suíça, consciente dos direitos humanos, compra camisetas de um vendedor na índia sob a condição contratual de que não sejam empregadas crianças na fabricação dos produtos. O comprador está disposto a pagar $100 \%$ a mais do preço de mercado para garantir o respeito a esses direitos humanos básicos. Se o vendedor quebrar o contrato por empregar crianças esse fato não altera fundamentalmente a propriedade tangível dos bens. Se o comprador revende os bens sem que ninguém esteja consciente da quebra do contrato, suas receitas vão ser as mesmas como se o vendedor tivesse cumprido com os termos do contrato. Assim, no sentido estrito, nenhuma perda pecuniária é verificada.

100 SCHWENZER, Ingeborg; HACHEM, Pascal; KEE, Christopher. Global sales and contract law. Oxford: Oxford University Press, 2012. p. 583.

101 SCHWENZER, Ingeborg; HACHEM, Pascal. The Scope of the CISG provisions on damages. In: SAIDOV, Djakhongir; CUNNINGTON, Ralph. Contract damages: domestic and international perspectives. Oxford: Hart Publishing, 2008. p. 94.
Hipótese 3: imagine que um fotógrafo profissional comprou uma Ferrari em cor-de-rosa chamativo pagando um extra por essa pintura especial para utilizar o veículo em sessões de fotos. A Ferrari é entregue em vermelho padrão comum. Como ninguém iria comprar uma Ferrari rosa chamativa, o preço de revenda de um vermelho padrão é ainda maior do que o carro negociado. Será que isso significa que o fotógrafo não sofreu perda e não pode pedir indenização? ${ }^{102}$

Assim, de acordo com a visão tradicional que restringe os danos às perdas econômicas, não haveria, em nenhuma das três hipóteses, danos a serem compensados, "ignorando-se o fato de que a parte prejudicada pagou o preço precisamente para obter o correto desempenho do contrato" $" 103$.

Por esse motivo, esses autores propõem a superação da concepção tradicional do benefício econômico por meio do que denominam princípio do desempenho

102 SCHWENZER, Ingeborg; HACHEM, Pascal. The scope of the CISG provisions on damages. In: SAIDOV, Djakhongir; CUNNINGTON, Ralph. Contract damages: domestic and international perspectives. Oxford: Hart Publishing, 2008, p. 94. Tradução livre de: Hypothetical 1: Suppose that the buyer is a commercial carrier buying 10 trucks for transportation. If they are not delivered in time, it rents substitute trucks to carry on its business. Rental costs will unanimously be recognized as pecuniary loss under the economic benefits principle. However, let us change the facts slightly. The buyer is no longer a professional carrier but a non-governmental organization (NGO) transporting food to the Sahel. As no substitute trucks can be rented where they are needed, no loss in this sense occurs. Hypothetical 2: Suppose that a Swiss company, conscious of human rights, buys T-shirts from a seller in India on the contractual condition that no children are to be employed in manufacturing the goods. The buyer is willing to pay a price $100 \%$ higher than the market price to ensure that such basic human rights are complied with. If the seller breaches the contract by employing children, this fact does not fundamentally change the tangible properties of the goods. If the buyer resells the goods without anybody becoming aware of the breach of contract, its revenues will be the same as if the seller had complied with the terms of the contract. Thus, in the strict sense, no pecuniary loss could be as certained. Hypothetical 3: Imagine that a professional photographer buys a Ferrari in a flashy pink colour, paying extra forth is special paint work for photo shootings. The Ferrari is delivered in ordinary standard red. As nobody else would buy a flashy pink Ferrari, there sale price of a standard red one is even higher than that of the car bargained for. Does this mean that the photographer has suffered no loss and cannot claim damages?

103 SCHWENZER, Ingeborg; HACHEM, Pascal. The scope of the CISG provisions on damages. In: SAIDOV, Djakhongir; CUNNINGTON, Ralph. Contract damages: domestic and international perspectives. Oxford: Hart Publishing, 2008. p. 94. Tradução livre de: “[...] one ignores the fact that the aggrieved party has paid the price precisely to obtain the correct performance of the contract". 
(performance principle), segundo o qual as obrigações contratuais assumidas pelas partes são contraídas de acordo com a vontade delas e de acordo com a lei, devendo, portanto, atuar-se no sentido de dar efetividade a esta vontade ${ }^{104}$.

À luz do princípio do desempenho é possível proteger as legítimas expectativas dos compradores nas três hipóteses anteriormente mencionadas o que representa a superação do paradigma puramente econômico comum ao século XIX, mas que já não é mais adequado às relações negociais contemporâneas reconfigurando a extensão dos danos abrangidos pela Convenção de Viena. ${ }^{105}$

Reforce-se que as categorias de danos apresentadas como recuperáveis neste estudo mediante aplicação do art. 74 da CISG estão em transformação sempre no intuito de proporcionar ao lesado à reparação integral do dano, mas sem propiciar-lhe o enriquecimento sem causa.

\section{Considerações finais}

A CISG, como instrumento de unificação do contrato de compra e vendainternacional de mercadorias representa um grande avanço em termos de segurança jurídica internacional. Contudo, a aplicação uniforme fica comprometida pelo uso de conceitos, cujo conteúdo tem necessariamente que ser preechido pelo intérprete, o qual inevitavelmente recorre à doutrina que lhe é mais próxima, qual seja, aquela que se dedica à hermenêutica do direito doméstico.

É interessante observar que é justamente nesse preenchimento dos conceitos que estão os principais pontos de divergência da doutrina. Assim, por exemplo, o artigo 25 da CISG define satisfatoriamente o que é inadimplemento essencial, porém, no momento em que se tem de definir o que é "privação substancial da legítima expectativa", os doutrinadores manifestam entendimentos divergentes.

Contudo, no que se refere ao problema exposto na introdução quanto à necessidade de existir um inadimplemento essencial para fixação de perdas e

104 SCHWENZER, Ingeborg; HACHEM, Pascal; KEE, Christopher. Global sales and contract law. Oxford: Oxford University Press, 2012. p. 584.

105 SCHWENZER, Ingeborg; HACHEM, Pascal. The Scope of the CISG provisions on damages. In: SAIDOV, Djakhongir; CUNNINGTON, Ralph. Contract damages: domestic and international perspectives. Oxford: Hart Publishing, 2008. p. 105. danos, verificou-se que a doutrina soa uníssona pela sua dispensabilidade, bastando que tenha havido uma violação a quaisquer das obrigações decorrentes do contrato ou da Convenção.

Partindo para análise dos casos concretos, contatouse uma subutilização do instituto das perdas e danos pelas partes, uma vez que elas geralmente sustentam o inadimplemento essencial para justificar a resolução do contrato.

Da comparação entre os vereditos dos casos selecionados, observou-se que não há padrões rígidos definidos a priori para o inadimplemento essencial, de maneira que a constatação da privação substancial de uma legítima expectativa é feita casuisticamente com base nas provas produzidas e nas circunstâncias específicas que envolvem a situação concreta, resultando, muitas vezes, em decisões díspares para casos semelhantes.

A identificação dos danos considerados recuperáveis pelo artigo $74 \mathrm{da}$ CISG resultou em quatro categorias já bem consolidadas pela doutrina, são elas: perdas diretas; danos incidentais; danos consequentes e lucros cessantes.

A principal polêmica se situa no campo dos danos consequentes e consiste na classificação do dano ao renome ou à reputação comercial como material ou imaterial. A doutrina internaciolista tem-se consolidado no sentido de que o dano ao renome é de caráter material e que, portanto, deve ser provado com razoável certeza.

Todavia, o assunto chama a atenção porque no Brasil a doutrina e a jusrisprudência há tempos assentaram o entendimento de que a pessoa jurídica pode ser vítima de dano moral, em que se enquadram os danos ao renome, à reputação e até à marca.

Optando por classificar tal dano como imaterial, os tribunais e a doutrina brasileiros pretendiam, e em certa medida conseguiram, eliminar o problema da prova nessas questões, confiando ao juiz a tarefa de arbitrar um valor suficiente para a reparação do dano.

Verifica-se nesse sentido um possível ponto de dissidência entre o que está consolidado no âmbito de aplicação da Convenção, ainda mais com a edição do parecer $n^{\circ} 06$ do Conselho Consultivo da CISG, e o que está consolidado no domínio dos tribunais brasileiros.

Resta a pergunta: será que os tribunais brasileiros estão dispostos a se comprometer com a uniformidade na aplicação da CISG? 


\section{Referências}

ALEMANHA. Corte de Apelação de Düsseldorf. Julgado em: 02, de julho de 1993. Disponível em: <http:// cisgw3.law.pace.edu/cases/930702g1.html $>$ Acesso em: 16 maio 2013.

ALEMANHA. Corte de Apelação de Köln. Julgado em: 12, de janeiro de 2007. Disponível em: <http://cisgw3. law.pace.edu/cases/070112g1.html $>$. Acesso em: 16 set. 2013.

ALEMANHA. Corte do Distrito de Berlin. Julgado em: 13, de setembro de 2006. Disponível em: <http://cisgw3. law.pace.edu/cases/060913g1.html > Acesso em: 16 jun. 2013.

ALEMANHA. Superior Tribunal de Köln. Julgamento em: 14, de outubro de 2002. Disponível em: <http://www. unilex.info/case.cfm?pid=1\&do=case $\& \mathrm{id}=860 \&$ step $=$ Abstract $>$. Acesso em: 14 ago. 2013 .

ALEMANHA. Superior Tribunal Regional de Frankfurt. Julgamento em: 18, de janeiro de 1994. Disponível em: <http://www.unilex.info/case. $\mathrm{cfm}$ ?pid $=1 \& \mathrm{do}=$ case $\& \mathrm{id}=40 \&$ step $=$ Abstract $>$. Acesso em: 14 ago. 2013.

ALEMANHA. Superior Tribunal Regional de Hamburg. Julgamento em: 28, de fevereiro de 1997. Disponível em: <http://www.unilex.info/case. $\mathrm{cfm}$ ? $\mathrm{pid}=1 \& \mathrm{do}=$ case $\& \mathrm{id}=291$ \&step $=$ Abstract $>$. Acesso em: 14 ago. 2013.

ALEMANHA. Superior Tribunal Regional de Oldenburg. Julgamento em: 22, de setembro de 1998. Disponível em: $<$ http:/www.unilex.info/case.cfm?pid $=1 \& \mathrm{do}=$ case $\&$ id $=5$ 06\&step=Abstract $>$ Acesso em: 14. ago. 2013.

ALEMANHA. Supremo Tribunal Federal Alemão. Julgamento em: 31, de outubro de 2001. Disponível em: $<$ http://cisgw3.law.pace.edu/cases/011031g1.html $>$. Acesso em: 08 ago.2013.

ALEMANHA. Tribunal de Apelação de Braunschweig. Julgamento em: 28, de outubro de 1999. Disponível em: <http://cisgw3.law.pace.edu/cases/991028g1.html> Acesso em: 14 ago. 2013.

ALEMANHA. Tribunal de Apelação de Frankfurt. Julgamento em: 17, de setembro de 1991. Disponível em: <http://cisgw3.law.pace.edu/cases/910917g1.html >. Acesso em: 05 ago. 2013.

ALEMANHA. Tribunal de Apelação de Hamm. Julgado em: 23, de março de 1978. Disponível em: <http://cisgw3. law.pace.edu/cases/780323g1.html>. Acesso em 19 set. 2013.

ALEMANHA. Tribunal de Primeira Instância de München. Julgamento em: 20, de fevereiro de 2002. Disponível em: $\quad<$ http://www.unilex.info/case.cfm?pid=1\&do= case $\& i d=904 \&$ step $=$ Abstract $>$. Acesso em: 14 ago. 2013.

BASEDOW. Jürgen. Towards a universal doctrine of breach of contract: the impact of the CISG. Disponível em: $<$ http:// www.cisg.law.pace.edu/cisg/biblio/basedow.html $>$ Acesso em: 13, ago. 2013.

BIJL. Maartje. Fundamental breach in documentary sales contracts the doctrine of strict compliance with the underlying sales contract. Disponível em: <http://cisgw3. law.pace.edu/cisg/biblio/bijl.html $>$. Acesso em: 05 ago. 2013.

BUTLER, Allisson E. A practical guide to the CISG: negotiations through litigation. Disponível em: $<\mathrm{http}: / /$ www.cisg.law.pace.edu/cisg/biblio/butler6.html $>$. Acesso em 14 maio 2013.

CHINA. Comissão Internacional Chinesa de Arbitragem Econômica e Comercial (CIETAC). Disponível em: $<$ http:// cisgw3.law.pace.edu/cases/960314c1.html $>$. Acesso em: 20, set. 2013.

CHINA. Comissão Internacional Chinesa de Arbitragem Econômica e Comercial (CIETAC). Julgado em: 12, de fevereiro de 1996. Disponível em: <http://cisgw3.law.pace. edu/cases/960212c1.html $>$ Acesso em: 16 set. 2013.

CHINA. Comissão Internacional de Arbitragem Comercial da China (CIETAC). Julgado em: 23, de julho de 1997. Disponível em: <http:/www.globalsaleslaw.org/content/ api/cisg/display.cfm?test=1895> Acesso em 27. maio 2014.

CISG Advisory Council Opinion $\mathrm{n}^{\circ}$ 6. Calculation of damages under CISG article 74. Disponível em: $<$ http:// cisgw3.law.pace.edu/cisg/CISG-AC-op6.html $>$ Acesso em: 06 jun. 2013.

CORDEIRO, Antônio Manuel da Rocha e Menezes. Da Boa-fé no direito civil. Coimbra: Livraria Almedina, 1984.

COSTA FILHO, Venceslau Tavares. Alguns aspectos da lei para a modernização do direito das obrigações na Alemanha. Revista de Direito Privado, ano 12, n. 45, p. 147-164, jan./mar. 2011.

COSTA, Judith Martins. Comentários ao novo código civil: do direito das obrigações: do adimplemento e da extinção das obrigações: arts. 304 a 388. 2. ed. Rio de Janeiro: Forense, 2006. v. 5. t. 1.

COSTA, Judith Martins. Os princípios informadores do contrato de compra e venda internacional na Convenção de 
Viena de 1980. Revista de informação legislativa, v. 32, n. 126, p. 115-128, abr./jun. 1995.

ESTADOS UNIDOS DA AMÉRICA. Corte Federal de Apelação da $7^{\mathrm{a}}$ Seção. Julgamento em: 19 , de novembro de 2002. Disponível em: <http://cisgw3.law.pace.edu/ cases/021119u1.html>. Acesso em: 28. Maio 2014.

FERRARI, Franco. Fundamental breach of contract under the UN sales convention: 25 years of article 25 CISG. Disponível em: $<$ http://cisgw3.law.pace.edu/cisg/biblio/ferrari14.html $>$. Acesso em: 05 ago. 2013.

FINLÂNDIA. Tribunal de Apelação de Turku. Julgamento em: 16, de junho de 1995. Disponível em: <http://www. unilex.info/case.cfm?pid $=1 \& \mathrm{do}=$ case $\& \mathrm{id}=797 \&$ step $=$ Abstract $>$. Acesso em: 14. ago. 2013.

FONSECA, Patrícia Galindo da. Anotações pertinentes à regulamentação sobre transmissão do risco: convenção da ONU de 1980, Incoterms e Código Civil brasileiro. Revista de Informação Legislativa, v. 35, n. 139, p. 39-56, jul./set. 1998.

FONSECA, Patrícia Galindo da. O Brasil perante uma nova perspectiva de Direito Mercantil Internacional. Revista Forense, v. 94, n. 341, p. 193-211, jan./mar.1998.

FRADERA, Vera Maria Jacob. A noção de contrato na convenção de Viena de 1980 sobre venda internacional de mercadorias. Disponível em: < http://www.cisg-brasil.net/ doc/vfradera1.pdf $>$. Acesso em: 08 mar. 2013.

FRANÇA. Corte de Apelação de Grenoble. Julgado em: 22, de fevereiro de 1995. Disponível em: <http://www.unilex. info/case. $\mathrm{cfm}$ ?pid $=1 \& \mathrm{do}=$ case $\& \mathrm{id}=83 \&$ step $=$ Abstract $>$. Acesso em: 14 ago. 2013.

FRANÇA. Tribunal de Comércio de Besançon. Julgado em: 19, de janeiro de 1998. Disponível em: < http://www. unilex.info/case.cfm?pid $=1 \& \mathrm{id}=416 \& \mathrm{do}=$ case $>$ Acesso em: 23. mai. 2013.

GLITZ, Frederico Eduardo Zenedin. Favor Contractus: alguns apontamentos sobre o princípio da conservação do contrato no direito positivo brasileiro e no direito comparado. Disponível em: <http://www.fredericoglitz. adv.br/biblioteca_detalhe/51/favor-contractus-algunsapontamentos-sobre-o-principio-da-conservacao-docontrato-no-direito-positivo-brasileiro-e-no-direitocomparado>. Acesso em: 05 ago. 2013.

GRAFFI, Leonardo. Case law on the concept of "Fundamental Breach" in the Vienna sales convention. Disponível em: <http://www.cisg.law.pace.edu/cisg/biblio/ graffi.html>. Acesso em 05 ago. 2013.

GREBLER, Eduardo; RADAEL, Gisely. Convenção das Nações Unidas sobre contratos de compra e venda internacional de mercadorias. Disponível em: <http:// www.cisg-brasil.net/doc/egrebler2.htm>. Acesso em: 06 mar. 2013.

HONNOLD, John. O. Uniform law for international sales under the 1980 United Nations Convention. Disponível em: < http://www.cisg.law.pace.edu/cisg/biblio/honnold. html>. Acesso em 02 set. 2013.

ITÁLIA. Tribunal de Forli. Julgamento em: 9, de dezembro de 2008. Disponível em: <http://www.globalsaleslaw.org/ content/api/cisg/display.cfm?test=1729> Acesso em: 27 maio 2014.

KOREA. Corte Distrital Central de Seoul. Julgado em: 5, de dezembro de 2008. Disponível em: <http://cisgw3.law. pace.edu/cases/081205k3.html\#uab $>$ Acesso em: 27 maio 2014.

KRÖLL, Stefan; MISTELIS, Loukas; VISCASSILAS, Pilar Perales. UN Convention on Contracts for the International Sale of Goods (CISG). München: C.H. Beck, 2011.

KRONMAN, Antony Townsend. Specific performance: yale law school legal scholarship repository. Disponível em: $<$ http://digitalcommons.law.yale.edu/cgi/ viewcontent. cgi? article $=2071 \&$ context $=$ fss_papers $>$ Acesso em: 16 maio 2013.

LIU, Chengwei. The concept of fundamental breach: perspectives from the CISG, UNIDROIT principles and PECL and case law. Disponível em: $<$ http://www.cisg.law. pace.edu/cisg/biblio/liu8.html>. Acesso em: 05 ago. 2013.

LORENZ, Alexander. Fundamental Breach under CISG. Disponível em: <http://cisgw3.law.pace.edu/cisg/biblio/ lorenz.html> Acesso em: 05 ago.2013.

NEUMAYER, Karl Heinz; MING, Catherine. Convention de Vienne sur les contrats de vente internationale de marchandises: commentaire. Lausane: Cedidac, Lausanne, 1993.

RACZYNSKA, Magdalena. Recoverability of the buyer's lost resale profit under CISG. Disponível em: $<$ http://www. njcl.fi/2_2007/article2.pdf> Acesso em: 16 set. 2013.

ROPPO, Enzo. O contrato. Coimbra: Almedina, 2009.

RÚSSIA. Tribunal de Arbitragem Comercial Internacional da Câmara de Comércio e Indústria da Federação Russa. Julgado em 27 de maio de 2005. Disponível em: <http://cisgw3.law. pace.edu/cases/050527r1.html >. Acesso em: 16 set. 2013.

SAIDOV. Djakhongir. Damages to Business Reputation and Goodwill. In: SAIDOV, Djakhongir; CUNNINGTON, Ralph. Contract damages: domestic and international perspectives. Oxford: Hart Publishing, 2008. p. 389-418.

SAIDOV. Djakhongir. The law of damages in the international sale of good: the CISG and other Internationsl Instruments. Oxford: Hart Publishing, 2008. 
SCHLECHTRIEM, Peter; BUTLER, Petra. Non-Material Damages: recovery under the CISG? Disponível em: $<$ http:// www.cisg.law.pace.edu/cisg/biblio/schlechtriem15.html>. Acesso em: 06 jun.2013.

SCHLECHTRIEM, Peter; BUTLER, Petra. UN law on the international sales: the UN Convention on the Internacional Sale of Goods. Wellington, Springer, 2009.

SCHLECHTRIEM, Peter; BUTLER, Petra; SCHWENZER, Ingeborg. Commentary on the UN Convention on the International Sale of Goods (CISG). 3. ed. Oxford: Oxford University Press, 2010.

SCHWENZER, Ingeborg; HACHEM, Pascal. The scope of the CISG provisions on pamages. In: SAIDOV, Djakhongir; CUNNINGTON, Ralph. Contract damages: domestic and international perspectives. Oxford: Hart Publishing, 2008. p. 91-106.

SCHWENZER, Ingeborg; HACHEM, Pascal; KEE, Christopher. Global sales and contract law. Oxford: Oxford University Press, 2012.
SILVA, Clóvis V. Couto e. A obrigação como processo. Rio de Janeiro: FGV, 2007.

UCRÂNIA. Tribunal de Arbitragem Comercial Internacional da Câmara de Comércio e Indústria da Ucrânia. 2005. Case n 48. Disponível em: <http://cisgw3. law.pace.edu/cases/050000u5.html $>$. Acesso em: 16 set. 2013.

UNITED NATIONS COMISSION ON INTERNATIONAL TRADE LAW (UNCITRAL). Commission Sessions. $<$ http://www.uncitral.org/uncitral/en/commission/sessions. html> Acesso em: 05 mar. 2013.

UNITED NATIONS. Convenção de Viena das Nações Unidas sobre contratos de compra e venda internacional de mercadoria. Trad. Eduardo Grebler e Gisely Radael. Disponível em: <http://www.cisg-brasil.net/doc/egrebler2. pdf> Acesso em: 14 abr. 2013.

WILL, Michael. Article 25: commentary. Disponível em: $<\mathrm{http} / / /$ cisgw3.law.pace.edu/cisg/biblio/will-bb25.html $>$. Acesso em: 05 ago. 2013. 
Para publicar na Revista de Direito Internacional, acesse o endereço eletrônico www.rdi.uniceub.br ou www.brazilianjournal.org.

Observe as normas de publicação, para facilitar e agilizar o trabalho de edição. 